\title{
Elements for a Comparative Study of Textile Production and Use in Hittite Anatolia and Neighbouring Areas
}

Vigo, Matteo; Bellucci, Benedetta; Baccelli, Giulia

Published in:

Prehistoric, Ancient Near Eastern and Aegean Textiles and Dress

Publication date:

2014

Document version

Early version, also known as pre-print

Citation for published version (APA):

Vigo, M., Bellucci, B., \& Baccelli, G. (2014). Elements for a Comparative Study of Textile Production and Use in Hittite Anatolia and Neighbouring Areas. In M. L. Nosch, C. Michel, \& M. Harlow (Eds.), Prehistoric, Ancient Near Eastern and Aegean Textiles and Dress: an Interdisciplinary Anthology (Ancient Textile Series ed., Vol. 18, pp. 97-142). Oxbow Books. 


\title{
5. Elements for a Comparative Study of Textile Production and Use in Hittite Anatolia and in Neighbouring Areas
}

\author{
Giulia Baccelli, Benedetta Bellucci and Matteo Vigo
}

\section{Introductory Overview}

"Words survive better than cloth". ${ }^{1}$ This statement is certainly valid for the ancient Near Eastern study of textiles.

Although our general knowledge regarding trade and use of textiles in the ancient Near East seems to be secure, particularly due to studies in the economic and administrative texts of Mesopotamia in the 3rd and 2nd millennium $\mathrm{BC}^{2}$, we do not yet have significant archaeological remains to confirm information provided by philologists. Over the last 50 years, scholars have been specifically investigating technical terms referring to textiles within texts.

If we look at the study of textile terms of the 2nd millennium Anatolia before the rise of the Hittite kingdom (17th-13th centuries BC), we observe the same lack; the information provided by textual evidence cannot be confirmed by iconography nor by the very scant archaeological remains. ${ }^{3}$

Monographs which address Assyrian trade in Anatolia during the 19th-18th centuries BC, ${ }^{4}$ provide information on textile production, costs and selling prices, workmanship, quality and shape of the fabrics, trade routes, "textile topography" (that is, the provenance and the final destination of particular fabrics). ${ }^{5}$ We are able to detect details regarding certain types of fabrics among the records of the Old Assyrian traders (personal letters written in Akkadian) found in the private archives of the commercial quarters of kārum Kaneš (modern Kültepe, near Kayseri, Turkey). ${ }^{6}$ These texts (written in a foreign language) speak of a foreign trade market controlled by a structured business system between the indigenous (Anatolians) and the traders (Assyrians).

What then can be said about the supposed Hittite textile production and economy of the following centuries in Anatolia?

\footnotetext{
${ }_{1}^{1}$ The present motto of emerita textile scholar Elizabeth Barber (Barber 1991, 260) was successfully recalled in the introduction of the recent proceedings on Textile Terminologies in the Ancient Near East and Mediterranean from the 3rd to the 1st millennium BC (Michel and Nosch 2010a).

${ }^{2}$ Among others Waetzoldt 1972; Veenhof 1972; Zawadski 2006; Breniquet 2008; Pomponio 2008; Verderame 2008; Biga 2010.

${ }^{3}$ It is worth to note that Cécile Michel (CNRS-ArScAn-Nanterre) and Eva Andersson Strand (CTR-SAXO Institute-University of Copenhagen) have recently started a systematic study of textile (and basketry) imprints on sealings from Kültepe.

${ }^{4}$ Above all, Veenhof 1972.

${ }^{5}$ Michel and Veenhof 2010; Wisti Lassen 2010a.

${ }^{6}$ For such letters, see Veenhof 1972, 103-115; Michel 2001; Wisti Lassen 2010b.
} 
Thanks to the information provided by other cuneiform texts found in Anatolia, such as administrative accounts of goods stored in the Hittite palaces, Hittitologists have produced indexes of realia (i.e. a presentation of the evidence of everyday objects used by the Hittites), in which luxurious textiles (or fabrics) and clothes often occur. ${ }^{7}$ Moreover, Hittite official texts such as the accounts of royal victories, the descriptions of cult activities and the diplomatic correspondence between royal courts almost always contain lists of precious textiles and garments as gifts given to gods or allocated to the palatial storehouses. Such documentation has contributed to the development of several important studies on textile terminology of Hittite Anatolia. Albrecht Goetze was one of the first Hittitologists who interpreted a number of Hittite words closely related to types of garments, most of which were worn by Hittite kings on different occasions (official ceremonies or worship). ${ }^{8}$ Although he rigorously analysed these Hittite textile terms from a linguistic perspective, Goetze made misleading comparisons with modern textile categories, in the quasi-absence - at that time - of evident archaeological data and technological experimentations. Nevertheless, because of his study scholars were able to obtain more information about types of garments, their colours, and, most notably, their supposed place of origin.

During the 1980s two fundamental editions of the Hittite palace inventories were published. ${ }^{9}$ This corpus $^{10}$ consists of few, often fragmentary, cuneiform tablets in the form of lists and memoranda of terms indicating items, supplies and materials, containers and places of storage, most of which are still awaiting a strict semantic interpretation. ${ }^{11}$ We may, therefore, define Košak's first edition of the Hittite inventory texts as a preliminary research on the "Hittite economic history" characterized by a strong lexical slant.

A few years later the Czech scholar Jana Siegelová, in order to study some aspects of the metallurgy of Bronze Age Anatolia, ${ }^{12}$ also investigated these inventories and increased the corpus (thanks to the discovery of new fragments and the study of many duplicates and joins). Her aim was to analyse each text to better understand the structure of the Hittite administration, the role of the various institutions and the officials involved in the process of storing of goods and their possible redistribution. ${ }^{13}$ The final result is a useful survey of the Hittite administration during the 13 th century BC; however, with regards to the study of textiles (that represent almost $80 \%$ of the items listed in these inventories) we have not yet made significant progress. Most of the terms that are thought to indicate the manufacturing, workmanship or shape of the fabrics remain difficult to determine, classify and translate.

Recent studies have updated and improved our knowledge of Hittite textile terminology. ${ }^{14}$ This is due, in part, to progress in the field of Hittite language studies and the discovery of new economic or administrative clay tablets from excavations of the Hittite capital, Hattuša, and provincial centres. After recent archaeological investigations we are now able to better define the function of a number of urban structures (storehouses, treasuries, archives). However, we still have no idea where the textile workshops were located and, most notably, how they worked.

\footnotetext{
${ }^{7}$ See the principle editions of Hittite palace inventory texts: Košak 1982; Siegelová 1986.

${ }^{8}$ Goetze 1947a; Goetze 1955; Goetze 1956.

${ }^{9}$ See the bibliography provided in note 7 .

${ }^{10}$ Such documents were first classified by Laroche in his CTH and thereafter updated by Košak (2002) according to the new archaeological discoveries.

${ }_{11}$ See recent observations by Mora 2007, 535-536.

${ }_{12}$ Siegelová 1984.

${ }_{13}$ Siegelová 1986, 547-568.

${ }^{14}$ See, for example, Klengel 2008; Vigo 2010.
} 


\subsection{Issues and Goals}

The geographical and chronological range is limited, as far as possible, to Hittite Anatolia of the 2nd millennium BC (Middle and Late Bronze Age),${ }^{15}$ crossing these limits, when necessary. Likewise, as a comparative study we cannot exclude close examination of those neighbouring areas from which we are able to obtain much more archaeological information on textile production and use than from the core of Anatolia. These neighbours encompass places located in the periphery of the Hittite Empire, especially Northern Syria.

The selected framework allows us to compare information provided by epigraphy, archaeology and iconography. ${ }^{16}$ However, an exhaustive research project on textile production and use in Anatolia during the 2nd millennium $\mathrm{BC}$ would require too extensive a study to be covered here. Hence, we present some elements for a comparative study, as a vade mecum, actually attempting to join the information provided by the rarely surviving archaeological finds in Anatolia and its neighbours with the written documentation. On the other hand, we also make an effort to fill gaps left by texts, in particular where "Hittite textile production" is concerned, matching archaeological data. For example, the study of the unearthed weaving tools could help to fill the almost absent information on crafting and weaving techniques in the written sources. The interdisciplinary approach is extended, where necessary, to an iconographical and iconological overview of the objects presenting processes of textile production. ${ }^{17}$

As with the majority of the interdisciplinary investigations, we would like all the issues to be solved or, at least, debated. This cannot be possible for many reasons, but we can provide glimpses on different matters. Since one of the most productive terminological Bronze Age categories for textiles seems to be "textile topology", we should establish whether items were simply channelled through the area or whether they are typical of that location because they were, for instance, crafted there.

Finally, pertaining to the use, as the majority of the written documentation deals only with luxurious textiles and does not give a complete overview of the many types of textile used in antiquity,$^{18}$ the exact definition of a "garment", "cloth" or "textile" is still a problematic issue, even if in recent times many studies have been devoted to clothing worn by rulers and elite. ${ }^{19}$

Any future interdisciplinary research should aim at understanding which are the untailored fabrics or the ready-to-wear costumes among those probably recorded in the Bronze Age archive documents of Anatolia and to better define the luxurious textiles carved on seal representations or on rock reliefs.

The same research methodology could be applied for colour indications, even if it is difficult to establish if a "coloured fabric" consists of dyed textile, a natural pigmentation, or both. ${ }^{20}$

\footnotetext{
${ }^{15}$ Period designations suffer many problems of synchronization between the different chronologies proposed by scholars of each single ancient Near Eastern culture. For an in-depth study on this topic see the international research project Associated Regional Chronologies for the Ancient Near East (ARCANE: http://www.arcane.uni-tuebingen.de/), even though limited for now to the 3rd millennium BC. For the archaeological period designations in Anatolia see, for example, Sharp Joukowsky 1996, 30-33.

16 For the importance of these comparisons see Michel and Nosch 2010b, x-xi. Cf. the interdisciplinary research programme on the Bronze Age textile production at Ebla (Syria) realized through a collaboration agreement between the Italian Archaeological Expedition at Tell Mardikh-Ebla (MAIS) and the Danish National Research Foundation's Centre for Textile Research (CTR). See Andersson et al. 2010.

${ }^{17}$ Such studies have recently been proposed as regards the new reading of the proto-dynastic iconography (Breniquet 2008; Breniquet 2010) and the Sargonic iconography (Foster 2010).

${ }_{18}$ See Michel and Nosch 2010b, xiii, with the bibliography provided in notes 51, 52.

19 Among others Biga 1992; Pasquali 2005; Sallaberger 2009; Michel and Veenhof 2010, 260-266; Vigo 2010.

${ }^{20}$ Cf. Michel and Nosch 2010b, xiii-xiv.
} 


\section{Sources for Textile Production from Archaeology, Epigraphy and Iconography}

\subsection{In Pursuit of Workshops}

The context of archaeological findings is particularly significant when focusing on textile tools, because by inspecting the environment in which these remains are found, scholars can better understand the tools themselves.

Through the analysis of archaeological objects within their context, it is possible not only to delineate the importance of textile production in the 2nd millennium BC in Anatolia and Syria, but also to define the techniques and kind of products involved.

Besides the archaeological value of textile tools, this analysis will also look at real textile remains or impressions on other materials: they complete and enrich the whole picture of textile production and use in daily life and within funerary contexts.

It is not possible to identify leading sites for textile production of the second half of the 2nd millennium BC in Anatolia only through archaeological data. It is worth mentioning the early 2nd millennium "Old-Assyrian" sites of Kültepe/Kaneš and Kaman-Kale Höyük. The former yielded materials for epigraphic and archaeological documentation concerning textile production; ${ }^{21}$ the latter yielded archaeological remains. ${ }^{22}$ Scholars have identified some textile workshops within houses or housing units for both these sites.

Workshops are often determined by the presence of weaving tools (loom weights; holes for loom structures). ${ }^{23}$ There are, in fact, two relevant situations in which the presence of loom weights can be found in an archaeological context. In the first one, the rows of the loom weights are intact, indicating that the loom was in use at the time of destruction/abandonment. The Gordion excavation provides an example dating to the 7th century $\mathrm{BC}$; fourteen large loom weights were found in two $60 \mathrm{~cm}$ long rows. ${ }^{24}$ In the second case the loom was no longer in use and loom weights were found grouped on a floor, probably because they were stored in a basket or a ceramic container. Hence, they indicate a sort of storage room, ${ }^{25}$ as in the so-called Gordion "Royal Storage House" ${ }^{26}$

The workshop of Gordion, now fully examined by Brendan Burke, is one of the most important for the study of the areas of textile production. ${ }^{27}$ The great finds in Gordion indicate mass textile production and provide archaeological evidence for a large number of textile workshops.

Regrettably, we do not have similarly clear workshops unearthed in Late Bronze Age Anatolian sites. But other possible workshops are presented in section 2.2., analysing the contexts of some findings.

\subsection{Archaeological Evidence: Tools and Contexts}

From an archaeological perspective there are a number of tools that refer to spinning and weaving in Anatolia as well as the surrounding areas during the 2nd millennium BC. Therefore, the following section examines tools such as spindles, spindle whorls and loom weights beginning with their morphological features and analysing the archaeological evidence.

\footnotetext{
${ }^{21}$ In particular, Veenhof 1972; Michel and Veenhof 2010.

${ }_{22}^{2}$ Fairbairn 2004.

${ }^{23}$ Loom weights are surely the most abundant archaeological evidence regarding weaving because of the less perishable material of which they were made compared to the wooden structure of the loom.

${ }^{24}$ Bellinger 1962.

${ }^{25}$ Barber 1991, 101-102; Shamir 1996, 144.

${ }^{26}$ Bellinger 1962.

${ }^{27}$ Burke 2010, in particular pages 108-157.
} 
Despite the small number of spindles found in archaeological sites, due to the perishable nature of the items, these objects are significant because of their symbolic value. ${ }^{28}$ Evidence from Alaca Höyük, dating back to the second half of the 3rd millennium BC, is particularly important. In grave $\mathrm{L}$ archaeologists excavated a silver implement with an electro head and a disc at its centre, the features of which resemble a spindle with a spindle whorl. ${ }^{29} \mathrm{~A}$ second spindle composed of precious metal was discovered in grave $\mathrm{H}$ in the same site. ${ }^{30}$ Similar metal tools, dating back to the 3rd millennium BC, have been found in graves of Horoztepe, ${ }^{31}$ Merzifon $^{32}$ and Karataş-Semayük. ${ }^{33}$

These remains are important because of their extraordinary features and funerary significance; they were found in the graves of high-ranking people. These tools did not meet functional needs because precious metals were not suitable for common use. They represent, instead, identity markers for social status. ${ }^{34}$ There is constant evidence of spindles made of precious material in funerary contexts and grave goods throughout the ancient Near East and the possible votive and ritual meaning of these tools highlights the symbolic value often related to textile manufacturing. ${ }^{35}$

During the Late Bronze Age and as early as the end of the Middle Bronze Age, spindles of bone or ivory often decorated with engravings also appear in archaeological records. This particular kind of spindle, mainly known from the neighbour Jordan/Region in Megiddo's graves, ${ }^{36}$ is attested during the Late Bronze III and the Iron I in Syria, Palestine and Cyprus,${ }^{37}$ but recent findings in Troy also indicate a larger spreading over Anatolia. ${ }^{38}$

The spindle whorl is a pierced tool used in the spinning process, located on a spindle to weight it down and ease the work. It allows the thread to spin in addition to accommodating the manufactured thread. In order to more precisely define this object it is helpful to delineate its main morphdimensional features. Therefore, it is important to measure consistently the weight and diameter of the object and the diameter of the perforation. An additional consideration that has to be taken into account is the spindle whorl's inertia, hence the ability of the object to perform its function.

At Arslantepe/Malatya (Anatolia) a significant number of spindle whorls have been excavated in both private and public contexts, dating back from the 4 th to the 2 nd millennium BC. ${ }^{39}$ The analysis conducted on the objects from Arslantepe is very important in the investigation of morphological parameters, like the diameter, the weight and the type of thread that can be obtained from their use. Through a careful treatment of the data, it was possible to underline a correspondence between the spindle whorl's shape and material. The majority of the spindle whorls from Arslantepe are made of bone and exhibit a convex or conical profile. However, others are made of clay, stone

\footnotetext{
${ }^{28}$ See infra $2.4 ; 3.2$.

${ }^{29}$ Koşay 1951, 169, L. 8, Pl. 197, fig. 1.

${ }^{30}$ Koşay 1951, 159, H. 115, Pls. 124, 126. See in general Völling 2008, 84-89.

${ }^{31}$ For the deposition in Horoztepe, see Özgüç and Akok 1958, 43-44; Pl. V-VIII.

${ }^{32}$ Cf. Völling 2008, 256, with bibliography.

${ }^{33}$ These objects are usually about $15 \mathrm{~cm}$-long and they present a metal spindle whorl put in the middle of the object while a tip presents a more or less elaborated surface. Cf. Bordaz 1980, 256.

${ }^{34}$ Cf. Peyronel 2004, 53; Völling 2008, 87-88.

${ }^{35}$ Peyronel 2004, 198. Völling 2008, 97-100. See further considerations in sections 2.4.; 3.2.

${ }^{36}$ Guy 1938, 170-172, fig. 175:6, Pls. 84, 1-16, 95, 41-50.

${ }^{37}$ For Hama and Enkomi, cf. Peyronel 2004, 53; Völling 2008, 87-88 with previous bibliography.

${ }^{38}$ In this case the spindle whorl from Troy is probably made from hippopotamus-ivory. Cf. Balfanz 1995; Völling 2008, 257-258.

${ }^{39}$ Frangipane et al. 2009, 6 and table 1. A new study by R. Laurito on Late Bronze Age textile tools found at Arslantepe was issued after the submission of the present paper (March 2014).
} 
and metal: the stone spindle whorls are mostly discoid or convex, while those made of clay often have a conical or bi-conical profile. ${ }^{40}$

Period VA, corresponding to the first centuries of the 2 nd millennium BC, presents a variety of spinning tools. ${ }^{41}$ Spindle whorls continue to be made of clay or stone, although, archaeologists have recorded a wider range of diameters and weights. "There may have been a change in the textile production with a larger variety of yarns being produced in later periods". ${ }_{42}$

A second example is the Anatolian site of Beycesultan, where we observe the presence of a large amount of fired clay spindle whorls, dating from the Middle to the Late Bronze Age. Almost all of them present a bi-conical profile and small dimension. ${ }^{43}$ In most cases the spindle whorls are decorated on the surface with curvilinear incisions. This geometrical decoration involving lines, zigzags and dots is typical of the Anatolian region and was also found in Tarsus ${ }^{44}$ as well as at Yanarlar. ${ }^{45}$

Turning to Syria, it is useful to recall a group of spindle whorls (55 objects) found at Ebla, dating to the first half of the 2 nd millennium BC. ${ }^{46}$ They are remarkably homogenous in shape and represent various typologies. The group appears to be rather standardized in terms of materials and shapes. It includes various types of stone such as agate, serpentine, basalt, soapstone and limestone, and commonly used materials such as clay and bone. The only spindle whorl dating back to the Late Bronze Age IA is made of serpentine and was found in a cistern-pit (P. 5213). ${ }^{47}$

The contexts of these findings are spread and it is interesting to note how their distribution can be non-homogeneous and without relevant concentration. ${ }^{48}$ Few objects come from the votive cisterns in the holy area of the Ištar Temple (dating to the Middle Bronze Age). ${ }^{49}$

The spindle whorls were often linked to domestic and productive contexts or, as in the Western Palace of Ebla, to some craftsmanship quarters inside the palace. ${ }^{50}$ Sometimes these tools are also connected to symbolic or ritual contexts as in the Royal Hypogeum located under the floor level of the southeast part of the palace. There are two spindle whorls that could be part of the funerary deposit of the "Tomba delle Cisterne"; one is made of limestone, the other of agate. ${ }^{51} \mathrm{~A}$ third one, made of bone, was uncovered in the corridor, between the "Tomba della Princepessa" and the "Tomba del Signore dei Capridi". ${ }^{2}$

The Late Bronze Age corpus of spindle whorls from the site of Ugarit represents the bestpreserved documentation for these instruments for the period..$^{53}$ They were found both in public

\footnotetext{
${ }_{40}$ Frangipane et al. 2009, 6-7, figs 2, 3, 8, 13.

${ }^{41}$ Such as spindle whorls, loom weights, brushes, beaters, spools, needles (Frangipane et al. 2009, 22).

${ }^{42}$ Frangipane et al. 2009, 26.

${ }^{43}$ Mellaart and Murray 1995, 118-120, 163, fig. O.13, 164, fig. O.14, 166, fig. O.16, 167 fig. O.17 195.

${ }^{44}$ They display profiles different from those of Beycesultan, despite the fact that they share the same geometrical decoration. Goldman 1956, 331-334, figs 447-450.

${ }^{45}$ Emre 1978, 113, Pl. 44. Spindle whorls with geometric decorations were found also at Gordion, in graves dating back to Early Bronze Age. Cf. Mellink 1956, 43, Pl. 24.

${ }^{46}$ Peyronel 2004, 161-168.

${ }^{47}$ Matthiae 1998, 570-572.

${ }^{48}$ On the contrary, in the Early Bronze Age levels a great concentration of spindle whorls was found in the same contexts. Cf. Peyronel 2004, 100-104; Andersson et al. 2010, 161-163.

${ }^{49}$ These cisterns were used until Late Bronze Age for votive and religious purposes after the destruction of the old Syrian city at the end of the 17th century BC. Cf. Peyronel 2004, 70.

${ }^{50}$ Peyronel 2004, 171.

${ }^{51}$ The use of rare materials is an indicator of a probable elite destination of these objects. Cf. Peyronel 2004, 172.

${ }_{52}$ Matthiae et al. 1995, 429.

${ }^{53}$ For Ugarit's spindle whorls, see in general Yon et al. 1987, figs 7, 22, 27, 49, 53, 57, 66, 68, 85. For stone spindle
} 
buildings and private houses. Through the study of these textile tools it is possible to note the typological evolutions of this kind of instruments in the second half of the 2 nd millennium BC. ${ }^{54}$

The majority of the spindle whorls found in Ugarit are made of stone and presents: a) a circular flat base with a dome-shape profile (almost conical in some cases) ${ }^{55} \mathrm{~b}$ ) a circular flat base, conical profile but concave sides. ${ }^{56}$ Spindle whorls made of bone and ivory present similar shapes but are less tall in profile (sometimes, almost flat disks) and exhibit a polished surface. ${ }^{57}$ Bone or ivory spindle whorls with a conical shape and concave sides are common in the Syro-Palestinian area in the last phase of the Late Bronze Age..$^{58}$ The production of tools made of precious materials (e.g. ivory) was particularly well known in Syria and Palestine during the Late Bronze Age and required highly specialized workshops. In Ugarit it was proven that there were specialized local manufacturers for these instruments. Similar typologies of spindle whorls found in Ugarit but also in Cyprus and in the south Palestinian area, suggest the possibility of contact among these regions. ${ }^{59}$

Taking into account the archaeological context, Ugarit provides two very interesting cases. The first example was the discovery of ten spindle whorls in Building F; the fact that at least six of the objects were from one room (No. 1222) suggests the existence of a specialized area which was devoted to spinning. ${ }^{60}$ The second case regards a small group of spindle whorls found in the "Temple aux Rhytons". It suggests that spinning activities could have been practised in the room nearby the sanctuary, directly connected with cultic activities. ${ }^{61}$

The site of Alalah is one of the most important centres for the production and diffusion of textile technology because of its strategic position for the trade routes between Syria and Anatolia. ${ }^{62}$

According to Woolley, spindle whorls made of different materials like stone, bone and clay were present in all the levels of the site. ${ }^{63}$ A selection was found on the floor of some rooms in the palatial building of the king Niqmepa, dating to the Late Bronze Age I. ${ }^{64}$ In Alalah, spindle whorls exhibiting low dome-shape profiles are prominent. ${ }^{65}$

A loom weight is an object used in the weaving process to give tension to the warp in a warpweighted loom. It must have a certain weight to keep the warp in traction. In the case of perforated loom weights a string, to which the warp is fastened, should pass through the hole. Loom weights were commonly found in Anatolian archaeological sites, with few examples from the Middle and Late Bronze Age Syria and Palestine. ${ }^{66}$ It is likely that the warp-weighted loom was already in use

whorls cf. Elliot 1991, 41-45; for bone and ivory, Gachet-Bizollon 2007, 19, 116. See now Sauvage 2013, focusing on spindle whorls coming from Ugarit in French museum collections.

${ }_{54}^{54}$ Spindle whorls are not commonly recorded for other Syrian sites. In Hama there is no evidence of these objects for the Late Bronze Age II. Also in Qatna there are scanty traces of these instruments. Cf. Peyronel 2004, 175; Baccelli 2011.

${ }_{55}$ Elliot 1991, 43, fig. 13 (4-14).

${ }^{56}$ Elliot 1991, 44, fig. 13 (5-21).

${ }^{57}$ Gachet-Bizollon 2007, 19, 116, Tav. 75.

${ }^{58}$ Peyronel 2004, 148.

${ }_{59}$ Peyronel 2004, 178; Elliot 1991, 44-45.

${ }^{60}$ Yon et al. 1983, 213-214.

${ }^{61}$ Mallet 1987.

${ }^{62}$ Woolley 1955.

${ }^{63}$ Woolley 1955, 271, Pl. 68c. Unfortunately, only a few decorated spindle whorls are shown in this publication.

${ }^{64}$ In rooms $6,7,8,16$ and 17 were found spindle whorls usually made of bone and mostly decorated with incised geometric motifs. Woolley 1955, 119-122.

${ }_{65}$ Peyronel 2004, 177.

${ }^{66}$ Peyronel 2004, 200. For the evidences of warp-weighted loom in the 4th and 3rd millennium BC, see Breniquet 2008, 274-277, figs 71,$72 ; 294-295$, figs 84 , 85; 297-300, figs 87-89. 
in Syria in the 2nd millennium BC, together with the ground horizontal loom. Loom weights in Anatolia and Cyprus date back to the Neolithic period ${ }^{67}$ Scholars suppose that the warp-weighted loom was brought to Syria through Anatolia. This kind of loom could have come from Europe (where it was in use since the Neolithic period) through the Aegean regions to Ancient Near East. ${ }^{68}$

The presence of looms in situ can be inferred from archaeological evidence not limited to loom weights. The case of Troy is clear: four rows of loom weights found on the floor of a room indicate the use of looms (in situ) and the specific designation of this room for weaving. ${ }^{69}$

More than one hundred loom weights coming from documented archaeological layers were found in the site of Arslantepe (Malatya).$^{70}$ They were made of different materials: stone, fired and unfired clay. The object shape was determined by its material; for example, unfired clay loom weights were usually hemispheric in profile, while fired clay loom weights were generally conical or discoid in shape. Loom weights dating back to the 2 nd millennium BC show more diversification. ${ }^{71}$ The majority of these tools come from the same domestic context. A large square room (A 58) contained 55 loom weights made of either stone or clay. ${ }^{72}$

In many Anatolian sites a significant amount of loom weights exhibit a typology characterized by a crescent profile with two perforations. This represents a variant common in central-western Anatolia during the 2 nd millennium BC. ${ }^{73}$ Remarkable is the case of 300 such items found in Karahöyuk, 70 of them in the same room. ${ }^{74}$

In the Absidenhaus in Demirci Hüyük were found 12 loom weights of the crescent typology together with a basin and a series of vessels. These objects were likely to be used in the preparation of thread and for weaving. ${ }^{75}$

A similar situation is found at Beycesultan, where a vessel and 31 unfired clay loom weights were excavated. ${ }^{76}$

Loom weights with conical and tronco-conical profiles were found in the 2nd millennium BC levels in Alişar Hüyük, Tarsus, Troy and Boğazköy. ${ }^{77}$

Almost 50 loom weights were found in Alaca Hüyük, dating back to the Hittite period. These objects were characterized by crescent or discoid shapes. ${ }^{78}$

Also belonging to this period are four weights found in Maşat Hüyük ${ }^{79}$ (exhibiting a crescent profile) and those found in Korucutepe (showing spherical profile).$^{80}$

${ }^{67}$ The very first evidence comes from the Neolithic levels of Çatal Hüyük with the presence of pierced loom weights. Burnham 1965, 173.

${ }^{68}$ Mellaart 1962, 56; von der Osten 1937, 42, 93, 214; Barber 1991, 300. From the site of Alişar Höyuk come some pyramidal loom weights with hole made of clay and dating back to the Neolithic period, founded direct on the floor of the domestic contexts.

${ }^{69}$ Blegen et al. 1950, fig. 461; Blegen 1963, 72.

${ }^{70}$ Frangipane et al. 2009, 8, 9, 13, 23, 25. fig. 9, fig. 25.

${ }^{71}$ The experimental analysis conducted on these tools from Arslantepe show that it was possible to weave the same kind of thread using loom weights with different weights and shapes. Cf. Frangipane et al. 2009, 22-25.

${ }_{72}$ Frangipane et al. 2009, 27.

${ }^{73}$ Völling 2008, 140. For the crescent shape loom weights in Anatolia, see now Wisti Lassen 2013.

${ }^{74}$ Trench C, Level I of the Room 25. Cf. Alp 1968, 73-76, Pl. 143, 439, Pl. 144-245.

${ }^{75}$ See Kull 1988, 10-11.

${ }^{76}$ Lloyd and Mellaart 1965, 51, fig. F2, 22; Völling 2008, 140. The same quantity of tools from Kusura were found in a context together with animal bones.

${ }^{77}$ For a general view of the sites with evidence of loom weights see Völling 2008, 137, tab. 3.

${ }^{78}$ Koşay and Akok 1966, 160-162, fig. 21.

79 Özgüç 1982, 120, fig. 61.

${ }^{80}$ van Loon 1978, 90, fig. 130. 
As suggested before, the discovery of such a large quantity of loom weights collected together could indicate either the employment or the storage and conservation of these tools in a specific room, probably designated for weaving activities.

Loom weights were also found in Syria, which allows scholars to draw geographical comparisons.

Only two loom weights from Ebla dating to the Middle Bronze Age are recorded ${ }^{81}$ Their shape is elliptic with the superior part of the tool quite rounded and the base flattened with an ovoid section. They were brought into light in the North Area P, in a layer linked to the later structures of the "Archaic Palace". Unfortunately, the complexity of the stratigraphic layers, does not allow a more precise collocation of these objects. ${ }^{82}$

In Ugarit, evidence of loom weights dates to Late Bronze I. A great number of clay tools with discoid shapes was analysed and found to be analogous to Cypriot loom weights ${ }^{83}$ It is reasonable to assume that these objects have a Cypriote provenance, rather than being an evolution of the conic loom weights employed usually in the Syrian region.

Loom weights from Alalah were collected from a small area of the north corner of the southwest wall of the private building (Level XIIB Room 10). Fifty loom weights made of lightly fired clay were found together with some pottery fragments. ${ }^{84}$ This evidence suggests that a specific corner of the house was designated to weaving with a warp-weighted loom. The second very interesting example is that of loom weights found in the palace of Niqmepa, (Level IV), in Room C8 ${ }^{85}$ This evidence could suggest the use of a warp-weighted loom during the Late Bronze Age, perhaps due to Anatolian influence. ${ }^{86}$

In conclusion, we can confirm the existence of spinning activities in Anatolia. However, because of the limited quantity of spindles and spindle whorls, we cannot assume that the production was comparable to that of Syria, which enjoyed a large and complex spinning production.

Taking into account the Middle and Late Bronze Age, weaving technology can be summarized as follows: weaving techniques remain the same throughout the Middle and Late Bronze Age in Anatolia and scholars observe the continuous use of the warp-weighted loom in domestic contexts. This would have been the most common instruments employed in weaving production in this area, although the well-known horizontal loom and the vertical two-beam loom were also used.

\subsection{Written Sources (Part One: The Production of Textiles)}

As already pointed out in the "Introductory Overview", even though textile production was of prime importance in the ancient Near East, ${ }^{87}$ not much evidence seems available both from archaeological ${ }^{88}$

\footnotetext{
81 Peyronel 2004, 199.

82 Peyronel 2004, 200.

${ }^{83}$ Elliot 1991, 40, 41, figs 12 (7-14); 13 (1-3).

${ }^{84}$ Woolley 1955, 23; Peyronel 2004, 201.

${ }^{85}$ Woolley 1955, 130, fig. 51B.

86 Peyronel 2004, 201.

87 See, in general, Bier 1995.

${ }^{88}$ We have many archaeological finds (textile tools) from different excavations. We know less about the real workshops. Cf. section 2.1. It is important here to remember the interesting database project of the Bronze Age Eastern Mediterranean textile tools. See Andersson et al. 2010, 160.
} 
and epigraphic contexts,${ }^{89}$ excluding a few representational pieces of evidence. ${ }^{90}$ The 2 nd millennium Anatolia does not represent an exception. ${ }^{91}$

Agnete Wisti Lassen has recently rightly stressed: "The perishable nature of archaeological evidence means that certain aspects of some crafts are completely lost, and it is often not possible to reconstruct processes and social religious aspects of the ancient crafts on the basis of physical remains alone. Studies in terminology can therefore corroborate both the archaeological evidence we possess, and shed light on issues not illuminated by archaeology at all",;2 hence, in this section are analysed many passages belonging to different text categories, selected as samples among the Hittite written sources; always bearing in mind that: "Textile production belongs to the periphery of the literate world, as it is frequently associated with the private sphere and the female gender". ${ }^{93}$

Private letters found in the ancient site of Kaneš (modern Kültepe, Turkey), provide us with interesting information about what was on demand on the markets in Anatolia during the first half of the 2nd millennium BC. Probably, they reflect a first stage of economic administration, essentially structured on local textile production in Aššr and, at the same time, on large scale distribution in Anatolia. Sifting through these letters, one can find some references to weaving techniques of that time. But these documents just inform us about textile production in Aššur.

Textile production in Aššur during the Old Assyrian Period was based on the labour of women, who actually spun and wove in their own homes. If we read the texts that regulated such domestic commitments, we can infer specifications of what was in demand on the markets in Anatolia, for example, through the detailed description on how a woven textile had to be processed. This is the case of a letter from the merchant Puzur-Aššur to the craftswoman, lady Waqqurtum (TC 3, 17) ${ }^{94}$

In his letter, Puzur-Aššur instructs Waqqurtum in how she should make her textiles in order for him to sell them on market. Lines 11-13 seem to be concerned with the finishing treatments of one side of such a textile; ${ }^{95}$ lines $14-18$ with the warping; ${ }^{96}$ lines $19-22$ with the finishing treatments of the other side of textile ${ }^{97}$ and lines $33-36$ with the size of textile. ${ }^{98}$ Hittite documentation lacks analogous and precise information.

\footnotetext{
${ }^{89}$ With the valuable exception of written sources coming from capital centres of Sumerian Mesopotamia (e.g. Isin), Northern Syria (Ebla), or Egypt (Amarna). See, therefore, Waetzoldt 1972; van de Mieroop 1987; Pomponio 2010 (amounts of wool supplied); Biga and Milano 1984; Archi 1985; Pomponio 2008 (entrusted textiles); Kemp and Vogelsang-Eastwood 2001. ${ }^{90}$ See section 2.4 .

91 Our knowledge of the Anatolian textile production during the Early Iron Age seems quite different, thanks to the excavations of the Gordion workshop. Cf. Burke 2005, Burke 2010, 108-157.

${ }^{92}$ Wisti Lassen 2010b, 270.

${ }^{93}$ This statement is purposefully paraphrased from Wisti Lassen 2010b, 271. In addition to this the author adds: "Also, as in many other ancient societies, Mesopotamia was home to a large textile production administered by palaces and temples and recorded by bureaucrats. Yet, the terminology of administrative records kept in such large organisations tends to be generalised and focus on raw materials and products rather than on actual work procedures and tool repertoire".

${ }_{94}$ Refer to Michel and Veenhof 2010, 249-250, for the latest treatment of this document.

${ }^{95}$ ša șubātim pānam išteènamma limšudū lā iqattupūšu: "One must strike the one side of the textile, and not shear it".

${ }^{96}$ šutûšu lu mādat ișsēer panîm șubātim ša tušēbilinni šaptam 1 mana-ta raddīma lu qatnū: "Its warp should be close. Add per piece one pound of wool more than you used for the previous textile you sent me, but they must remain thin". ${ }^{97}$ pānam šaniam i-li-la limšudū šumma šārtam itaš' ’̂ kima kutānim liqtupūšsu: "Its second side one should strike only lightly. If it proves still to be hairy, let one shear it like a kutānum".

${ }_{98}$ gamram șubātam ša tepišini tiše inammitim lu urukšu šamānē ina ammitim lu rupuššs: "A finished textile that you make must be nine cubits long and eight cubits wide".
} 


\section{Lú/MUNUSUŠS.BAR (Male/Female Weaver)}

We can assume from a passage of the "Hittite Laws" that weavers were considered professionals:

"If anyone gives (his) son for training either (as) a carpenter or a smith, a weaver or a leather worker or a fuller(?), he shall pay 6 shekels of silver as (the fee) for the training. If he (the teacher) makes him (i.e. the son) an expert (and retains him in his own employ?), he (the teacher) shall give to him (i.e. to the parent) one person." 99

We know that weavers involved in the palace system were sometimes assigned to different duties as skilled labour. For example, this cult inventory reports:

"[In the ci]ty of Uwalma, His Majesty has assigned to the gods what follows: one estate, wherein ten deportees [of?] ${ }^{100}$ high ranking state dependents(?); ${ }^{101}$ one estate, wherein 16 deportees of (assigned as/belonging to?) mountaineers; one estate, wherein ten deportees, servants of Mr Innara; one estate, wherein four deportees of the priest; one estate wherein ten deportees, weavers of the king. The total is: five estates, including 50 deportees and 50 previous sheep (i.e. belonging to former estates or personal ownerships)." 102

Similarly in the cult inventory of Pirwa it is stated:

"His Majesty has instituted the following things: [...] 40 deportees (as?) weavers of the town of Hariyaša." 103

Hence, we can infer that weavers were generally not free craftsmen:

"If anyone buys a trained artisan - either a potter, a smith, a carpenter, a leather-worker, a fuller(?), a weaver, or a maker of leggings(?) - he shall pay ten shekels of silver."104

A passage of the treaty between Muršili II and Targašnalli of Hapalla, included in the fugitives' clause, ${ }^{105}$ states as follow:

"But [if] he is a cultivator, or a weaver, a carpenter, or a leather-worker-whatever sort of craftsmanand he does not [deliver] his assigned work, [but] runs off and comes to Hatti, I will arrest him and give him back to you." 106

We have clear exemptions of this kind of provisions in case a man becomes a weaver in "holy cities", like Arinna:

"Formerly the house of a man who became a weaver in Arinna was exempt; also his heirs and relatives were exempt." 107

Like many other professions among the Hittites, palace weavers had a hierarchy. A chief of the weavers is involved in a rite for the royal couple:

\footnotetext{
${ }_{99}$ KBo VI 26++, col. IV 27-31. Cf. Hoffner 1997, 158-159, with note 573.

${ }^{100}$ For this restoration see D'Alfonso 2010, 77-78.

${ }^{101}$ For the term LÚ.MEŠ GišTUKUL.GÍD.DA, see recently D'Alfonso 2010, 76-78.

102 KUB XLVIII $105+$ KBo XII 53, obv. 31-34.

${ }^{103}$ KUB LVII 108 (+) KUB LI 23, obv. II 7', 13'. Cf. Hazenbos 2003, 103-105.

${ }^{104}$ KBo VI 26, col. II 21-26 (§ 176b). Cf. Hoffner 1997, 140-141.

${ }^{105} \mathrm{KBo} \mathrm{V} 4$, obv. 35-40 (§ 6).

${ }^{106}$ Beckman 1996, 66. The same statement recurs in a passage of the treaty between Muršili II and Kupanta Kurunta (KUB VI 44++, col. IV 34-45). Cf. Beckman 1996, 75.

${ }^{107}$ KBo VI 3+, col. III 3-4 (§ 51). Cf. Archi 1975, 331; Hoffner 1997, 63.
} 
"Two palace officials are squatting before the queen. They are holding a karza(n)- (from) below. ${ }^{108}$ The chief of the weavers gives plaited ${ }^{109}$ white wool to the chief of the palace officials. The chief of the palace officials braids it once. The chief of the palace officials gives it to the king. The king (braids) it twice and winds (it) around ${ }^{110}$ the karza(n)-."111

In a parallel passage we find the chief of weavers in a similar context. ${ }^{112}$ Weavers were sometimes in charge of cult offerings, as stated in a number of fragmentary passages of instructions for cultic celebrations. ${ }^{113}$ Weavers enrolled in the palace system seem coordinated by the weavers' overseer (UGULA LÚ.MEŠUŠ.BAR), as testified at least once in a land grant tablet of the king Arnuwanda I and his wife Ašmunikal. ${ }^{114}$ It is important to remark that the information provided by the Landschenkungsurkunden (land grant documents) ${ }^{115}$ points to a corporate organization of skilled textile labour activities in Hittite Anatolia, even if we cannot exclude cases of housework commitments. Female weavers are surprisingly attested, together with cowherds (LÚ.MEšSIPA.GU ${ }_{4}^{\text {HI.A) }}$ ) and shepherds ( ${ }^{\text {LU.MEŠSIPA.UDU }}{ }^{\text {HI.A }}$ ), only in a fragmentary passage of the Ritual of Zuwi:

"The female weaver cleanses the cowherds and the shepherds."116

Similarly, female and male ${ }^{117}$ weavers, offspring ${ }^{118}$ of the underworld goddesses, Ešduštaya and Papaya, cited in the "Ritual of Kingship" (CTH 414.1) should be considered as ritual functionaries: ${ }^{119}$

"Halmašuit (i.e. the royal throne) says to the king: «Now bring their sons to the palace window: the skilled female and male(?) weavers». Before (one group) of them he (the priest?) places the zapzaki ${ }^{120}$ and strews figs (thereon?); before the other he places kinupi (crockery?) and strews raisins and dried fruits (thereon?) (saying): "Soothe ye the king»."121

\footnotetext{
${ }_{108}$ For the meaning of $\operatorname{karza}(n)$ - see below.

${ }^{109}$ As per Melchert 1998. We wonder if taruppand[an] could indicate in this context plucked wool.

${ }^{110}$ Here we follow CHP, "L-N", 360.

${ }^{111}$ IBoT II 96, col. V 5-13. Lastly Melchert 2001, 405.

112 KUB XI 20, obv. I 2-16. See below the translation of the passage. Cf. Melchert 2001, 404.

113 KUB LVIII 7, obv. II 15: [LÚ.ME]Š UŠ.BAR da-an-zi. Cf. Hazenbos 2003, 41-42; Groddek 2005, 21. An additional fragment citing male weavers in charge of cult offerings for the Storm-God of Aleppo (KBo XIV 142, col. IV 6) can be added.

${ }^{114}$ KBo V 7, rev. 27.

${ }^{115}$ For this group of texts (LSU) see the fundamental work by Riemschneider 1958.

${ }^{116}$ KUB XII 63+, obv. 14.

${ }_{117}$ KUB XXIX 1, col. II 13. According to Marazzi (1982, 164), the second Sumerogram in line 13, should be read LÚ.MEŠBAR.DUL ${ }_{8}$. Therefore it could be a copyist's misunderstanding considering the Late Hittite copy in the same passage (KUB XXIX 2, col. II 5): LÚ.MEŠU[Š.BA]R?. Cf. HZL, 100, No. 20. We wonder if LÚ.MeŠBAR.DUL L $^{\text {DAB might }}$ refer to another profession. Cf. MZL 275, No. 121. For the translation of ${ }^{\text {Lú.MEŠBAR.DUL }}$, see the online edition by Görke (2012) in http://www.hethport.uni-wuerzburg.de/hetkonk/ s.v. CTH 414.1.A.

118 KUB XXIX 1, obv. II 12: DUMU.DUMU ${ }^{\text {MEŠs }}$ SU has to be referred to the weavers as per Marazzi 1982, 152-153, 164 in particular. Cf. Görke (2012) in this passage.

${ }^{119}$ Cf. Haas 2003, 24.

${ }^{120}$ A glassware? See already Goetze 1947b, 313-315.

${ }^{121}$ KUB XXIX 1, obv. II 13-17.
} 


\section{LÚÁZLAG [ [ỨTÚG] ${ }^{122}$ (Male Washer/Fuller?)}

The ${ }^{\text {LÚ.MEŠ́ }}$ ZLAG are usually thought to be fullers. ${ }^{123}$ In past times some doubt has been cast on this. ${ }^{124}$ We know, in fact, that in Ancient Mesopotamia (e.g. during the Ur III Period), woollen cloths were not heavily fulled. ${ }^{25}$ Indeed, looking at the bulk of the Mesopotamian attestations of 2 nd millennium BC, it is difficult to propose that this Sumerogram always refers to fulling activities. Accordingly, the Sumerogram in Hittite texts can hardly been interpreted as fuller(s):

"Even as the Lú.MEš́źZLAG [ma]ke linen sheer ${ }^{126}$ and clean $\left[\mathrm{se}{ }^{127}\right.$ it of fuzzes, and it becomes white, may the gods likewise cleanse away [this] person's bad disease." 128

The situation reflected in this passage should be the cleaning of linen. Since this passage is the most comprehensive so far and we have no other Hittite sources to propose a translation Lú.MEš́'AZLAG "fullers" or the more general "finishers", we would cautiously propose "washers". ${ }^{129}$

A ${ }^{L U}$ ÁZLAG is mentioned in a land grant document of Arnuwanda $\mathrm{I},{ }^{130}$ maybe belonging to the house of Šuppiluliuma (the "scribe on wooden tablet(s)"), among other people included in the estate given by Arnuwanda himself and the queen Ašmunikal to the queen's attendant, Kuwatalla. A "house of washer" (É LÚÁZLAG) is also attested, even if it appears in a very fragmentary ritual context. ${ }^{131}$ In a tablet of the cult of Nerik, some "washers" seem involved in a ritual together with other palace attendants. ${ }^{132}$

The quasi-absence of attestations of female ÁZLAG in the Hittite written sources, cannot demonstrate that such activities were set aside for men because it was a hard job. Nevertheless, this lack of references should not be underestimated. ${ }^{133}$

In two different texts washers are mentioned along with a name of a town, namely Taštariša, which should have been laid in the territory of Nerik, somewhere around the modern towns of Zile and Tokat, in North-central Turkey. ${ }^{134}$ Once more they are involved in cult activities. ${ }^{135}$

\footnotetext{
${ }^{122}$ For the current readings, see HZL, 198, No. 212.

123 See, for instance, Gelb 1955, 234, with previous literature. Cf. Akk. ašlāku in CAD “A/2”, 445-447, last page in particular.

${ }^{124}$ Cf. already Leemans 1960, 64, note 4.

125 Cf. Waetzoldt 1972, 153.

126 Christiansen $(2006,45)$ translates: "[säuber]n".

127 This interpretation of [arha] parkunu- seems quite satisfactory, Cf. Christiansen 2006, 45: “entfernen".

128 KUB XXVII 67, col. II 26-30.

129 Two points are debatable. First, we cannot assure that GADA (with phonetic complementation! [-an]) refers to a linen cloth. It could be simply flax, even if it should usually come with the determinative (GIŠ). In the latter case we would suggest "washers" more than "fullers" (retting process?). Secondly, the fact that GADA after the LÚ.MEš ÁZLAG's treatment becomes white (harkǐši $)$ could point to (a) fulling process(es) of a linen cloth instead.

${ }_{130}$ KBo V 7, obv. 19, rev. 13, 41.

131 KBo IX 125, col. IV 3.

132 KUB LVI 54, rev. 26, with duplicates.

${ }^{133}$ KUB XXV 11, col. III 5. Looking both at the hand-copy and at the photo of the tablet, we would not include even this unique attestation, because we cannot assure that the last sign in MUNUS ${ }^{\text {MEŠ }}$ ÁZLAG? is indeed a variant of ÁZLAG or TÚG. The scanty attestations in Mesopotamian texts of 2nd millennium BC are noteworthy. Cf., for example, Waetzoldt $1972,154$.

${ }^{134}$ Bo 6002, obv. 4; KUB LX 131, r. col. x+1-2. Cf. Lebrun 1976, 187-188. For the suggested locations see RGTC VI, 412; VI/2, 164-165.

${ }^{135}$ In KBo XXXIV 242, rev. 6 (duplicate of KUB LX 131, 1'-7') we read: [(ma-a)]-an 2 LÚ.MEš ÁZLAG 2 MUNUS.MEŠUŠ[BAR?
} 


\section{LÚGAD.TAR (Tailor?)}

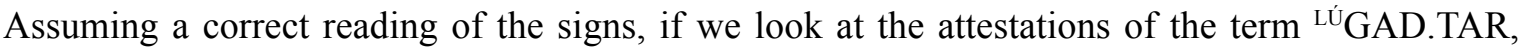
there is no certainty that it deals with any profession related to textiles production. ${ }^{136}$ With regards to this, the lexical list KBo I 30 (9') $)^{137}$ offers us a misleading lexical equation ( ${ }^{\mathrm{L}} \mathrm{gad}$.tar =lu-ga-ad$\operatorname{tar}=n u$ - $\left.^{\prime}-u^{\prime}=d a m-p u-p i-i s\right)$. As rightly observed by Klinger ${ }^{138}$ the obscure meaning of the logogram is confirmed by the fact that both the Akkadian and the Hittite terms (n $\hat{u}$ ' $u$; dampupi-) are matched with two different logograms. ${ }^{139}$ Based on the context of attestations, ${ }^{140}$ we would rather suggest

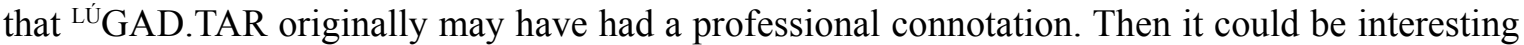
to know the real meaning of the equivalent Hattian term "Útušhawa dun tanišawe listed in the "Instructions for the gatemen". ${ }^{141}$ In any case, by the time the texts containing this term were written,

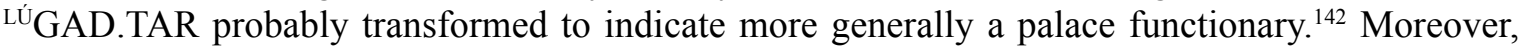
the curious form LÚ.MEškat-ta-ru-ut-ti-šs? $a$-za of KUB LV 5, col. IV $8{ }^{143}$ speaks once more against the identification with the Hittite term dampupi-, despite the supposed misinterpretation because

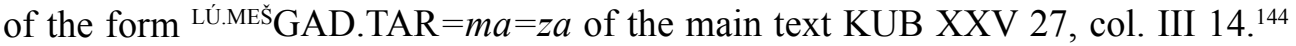

We have no Hittite texts that allow a clear reconstruction of the whole textile manufacturing process. The Hittite documentation offers us sporadic references to textile tools and techniques. Once more, we know from ritual texts that the yarn (kapina-) ${ }^{145}$ is separated (mârk- ${ }^{i} /$ mark-$^{-}$, partae- $^{z i}$ ); ${ }^{146}$ the wool (SÍG/hulana-) can be drawn/drafted (huitt(iye/a) $\left.{ }^{z i}\right),{ }^{147}$ tied (hamank- ${ }^{i} /$ hamel $^{2}$ ink-), ${ }^{148}$ cut off/removed ([arha $]$ tuhs $\left.s^{a(r i)}\right),{ }^{149}$ spun (mälk-i/malk-), ${ }^{150}$ and clean[s]ed ([arha $]$ parkunu). ${ }^{151}$ Textile tools used during the manufacturing process encompass spindle ( $\left.{ }^{(\mathrm{GIS})} h u e / i \check{s} a-\right),{ }^{152}$ distaff

${ }^{136}$ Differently Pecchioli Daddi $(1982,53)$ suggests, with reservations, to translate it "tailor". For a full discussion of this Hittite logogram see Weeden 2011, 227-229.

${ }_{137}^{137}$ MSL XII, 214-215.

${ }_{138}$ Klinger 1992, 191.

139 KBo I 30, 8': LÚaš.hab lu-aš-ha-ab nu-'-ú dam-pu-pí-iš. The basic meaning of LÚAŠ.HAB (Akk. išhappu<Old Babylonian ašhappu) "rouge, villain" throws an interesting light on the possibility that the scribe simply has repeated the lexical equation in line 8 and 9. For Akk. nû'u meaning either "foreigner", "uneducated man", see Weeden 2011, 228 , note 1017 , with previous bibliography.

${ }^{140}$ Cf. Pecchioli Daddi 1982, 53.

${ }^{141}$ KBo V 11+KUB XXVI 23, col. I 17. Cf. Soysal 2004, 318, 838-839. Weeden $(2011,228-229)$ reports further suggestions.

${ }^{142}$ Cf. HZL, 174, No. 173: "ein Funktionär?". Otherwise one would think of a Hittite logogram from an unattested Akkadian professional designation †qattārum "incense-burner" or more specifically the one who offers meat and fumigates the statues of the gods and other stuff with animals' hairs. It would fit better with the context of the scanty occurrences

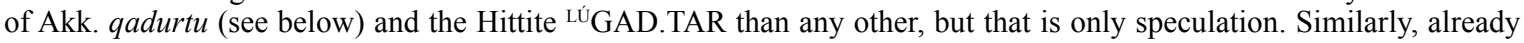
Weeden 2011, 229.

${ }^{143}$ Nakamura $(2002,56)$ has transliterated ${ }^{\text {LÚ.MEŠ } Q A ̇ T-T A-R U-U T-T I, ~ p r o b a b l y ~ w i t h ~ r e f e r e n c e ~ t o ~ t h e ~ N e o-A s s y r i a n ~ h a p a x ~}$ qadaruttu (meaning unknown), cognate of qadurtu. Cf. CAD “Q”, 45-46. We cannot even exclude † †ú.MEš GAD.TAR-UT$T I-s ̌ a-z a$ with bilingual (Akkadian and Hittite) phonetic complementation as Weeden $(2011,228)$ has already suggested.

${ }^{144}$ Houwink ten Cate 1988, 176. Cf. Nakamura 2002, 56-57.

${ }^{145}$ Cf. HED "K", 65.

${ }^{146}$ Cf. CHD "L-N", 187; "P”, 197-198.

${ }^{147}$ Clearly in KUB XXVII 67, col. II 15-24.

148 See the examples in HED "H", 64-67.

149 E.g. KBo IV 2, col. I 28-29, 31-32, 36-39; VBoT XXIV, col. I 22-24; KBo XXXIX 8, col. II 9-10; KBo XLVI 38, col. I 5-6.

${ }^{150}$ See the passages cited in CHD "L-N", 131-132.

${ }^{151}$ Cf. CHD "P", 174.

${ }^{152} \mathrm{HW}^{2}$ Band III/2, 632-633. 
((GIš) hulāli-), ${ }^{153}$ and spindle whorl (panzakitti-). ${ }^{154}$ Then the spun wool (malkeššar?) ${ }^{155}$ can be cleaned of impurities ('(SiG) mariȟsi-), ${ }^{156}$ looped forming knots ((SíG)pittula-). ${ }^{157}$ These bundles of wool can come in large quantities. In a palace inventory coloured wool is listed. It is not completely clear if the material is assigned by the queen to a palace attendant, namely Anni; or if Anni herself has already made wool yarns out of a roving ( ${ }^{\mathrm{Sig}} M U K K U$ ? ${ }^{158}$ and she gives them to the palace. ${ }^{159}$ Anyway, it is reasonable to suppose that Anni takes charge of some textile activities. A huge amount of wool seems to be looped, even if it contains impurities. ${ }^{160}$ Unfortunately, apart from Anni, only few women among the 22 quoted in the Hittite palace inventories seem to be connected to textile activities. ${ }^{161}$ The majority is mentioned in connection with finished products allocated in palace storehouses or given as gifts to the queen. About 12 women seem to be entrusted to textile production, despite the difficulty in interpreting the term SÍG gaši $(\breve{s})$ - of KBo XVIII 199(+)KBo II 22 as untreated wool. ${ }^{162}$ The best written source we have so far about textile techniques and tools is the aforementioned ritual (for the fertility?) ${ }^{163}$ that involves the royal couple (CTH 669.9). In a relevant passage it is stated:

"The chief of the wooden tablet scribes and the chief of smiths bring malkeššar (spun wool?). They pass in front of the fireplace. The chief of the smiths gives it (spun wool?) to the chief of the wooden tablet scribes. The chief of the wooden tablet scribes in turn gives (it) to the chief of the waiters, and he hangs (it) from a table. The king and the queen take white and red wool from the karza(n)-, and join/tie (taruppanzi) them (together) and they $m[a] k e$ them into loops/knots? (pittuluš)."

In a second passage of the same ritual something more interesting is reported:

"The chief of the palace officials takes a (wool) kunzan and ties it onto a (piece of) wood. The chief of the table-men hangs it (i.e. the wood stick) from a table. The chief of the weavers mix white and red wool. He gives the belt to the chief of palace officials and he puts it on/in his antaka (loins or chamber?). ${ }^{165}$ One escorts out the chief of the weavers. The acrobat cries "aha!" The chief(s) of the palace officials escort(s) in a shepherd. He takes the karza(n)- and carries it out." 166

Needless to say that we are dealing with a ritual. Thus, it must be underlined that the text itself has a strong magical value and a clear metaphorical connotation. According to Melchert the mixing of the white and red wool should symbolise the successful sexual union of male and female. ${ }^{167}$ At any

\footnotetext{
${ }^{153} \mathrm{HW}^{2}$ Band III/2, 691. For the terms spindle and distaff see also Ofitsch 2001, with previous bibliography.

${ }^{154}$ CHD "P", 95-96.

${ }^{155}$ Cf. CHD "L-N", 132. We wonder if this deverbal abstract noun can be translated "wool ready to be spun". Cf. EDHIL, 550.

156 Cf. CHD "L-N", 186-187.

${ }^{157}$ Cf. CHD "P", 365-366. The term means generally "loop". According to the attestations, the (Sí) pittula- is something used to tightly fasten hands. However, it cannot be excluded that bunches of fibres could come in loops as well.

${ }^{158}$ It could simply indicate a bad quality of wool. Cf. CAD "M/2", 187-188.

159 KUB XLII 66, rev. 7'-8': $k \bar{\imath}=m a=k a n{ }^{\text {Síg }} M U K K U$ ku-[xxx $] A N A{ }^{\mathrm{F}} a n n i=k a n$ arha $d[\bar{a} i$ ? See the parallel text KUB XLII 102, 6": " $a$ ]nni? peran arha dāi. For the construct arha + kan (+ motion verb) refer to Hoffner and Melchert 2008, 369 (\$28.65). Cf. Mora and Vigo 2012, 180-181.

${ }^{160}$ KUB XLII 102, 10": 10 MA.NA ${ }^{\text {Síg pittulaš } Q A D U}: \operatorname{marih}[\check{s}$ š $]$.

${ }_{161}$ Cf. Mora and Vigo 2012, 177, 180.

162 See Mora and Vigo 2012, 177-180, for a close examination of the term.

${ }_{163}$ As per Melchert 2001.

164 IBoT II 94, col. IV 4-15.

${ }^{165}$ For the meaning of antaka/i- in particular contexts see Melchert 2003.

${ }^{166}$ KUB XI 20, col. I 5-21=KUB XI 25, col. III 2-14.

167 Melchert 2001, 407.
} 
rate we believe that in the relevant passages a description of a real handwork is illustrated. Strange as it may seem, the chief of the weaver is really plaiting wool using a very simple technique. A stick made out of wood is hung on a table surface and then wools of different colours are mingled. Since red and white wool are taken from the $\operatorname{karza}(n)$, we would agree with Melchert in considering this object a sort of niddy noddy. ${ }^{168}$ We cannot be sure that the braided belt is the result of white and red wool only, or if the kunza- was plaited together. We would not even exclude that kunzacould be a particular device ${ }^{169}$ hung to a surface (door, wall or table) to help the stick to maintain the tension. It is interesting to note that every person involved in the ritual plays a specific role, as usual in these kinds of ceremonies. In particular, the chief of the weavers has to mix together the red and white wool that we presume were passed to him by the royal couple and, at the very end, the shepherd carries out the basket of wool possibly containing just a bunch of fibres. Considering the difficulty of a correct interpretation of the passage, one could ask whether the process depicted in this ritual might instead point to a doubling technique (in fact cording), as opposed to a draftspinning of two or more threads. So, the white and red wool taken from the basket by king and queen are joined together by simply plaiting the fibres. ${ }^{170}$

The Hurrian textile production is well attested in the Hittite epigraphic sources. ${ }^{171}$ We cannot exclude that corporations of skilled Hurrian weavers in Hattuša and in other Hittite palatial centres did exist, producing items that were typical of their native lands. ${ }^{172}$ In a land grant tablet of the king Arnuwanda I and his wife Ašmunikal in favour of Kuwattalla, the queen's attendant, among the estates of the scribe on wooden tablet(s), Šuppiluliuma, is listed the estate (literally "the house") of a certain Muliyaziti, the "Hurrian shirt maker" ( ${ }^{\mathrm{L}} E P I S ̌$ TÚG.GÚ.È.A HURRI). ${ }^{173}$

Linen came primarily from Egypt; wool from Anatolia and Northern Syria. Many textiles made of linen or wool were probably dyed in the Eastern Mediterranean islands and coasts, such as Cyprus (Alašiya), ${ }^{174}$ Ugarit or Lesbos (Lazpa). ${ }^{175}$ In a passage of a prayer to the Sun-goddess of Arinna, the Hittite king Muršili II characterises the semi-nomadic population of the Pontic region, namely the Kaška, as "swineherds and linen weavers". ${ }^{176}$ Because both occupations were generally, but not always, performed by women, this exceptional comment could be read as an insult. Remains of flax plants dating back to the Middle Bronze Age have been found on the Black Sea coasts. ${ }^{177}$

\footnotetext{
${ }^{168}$ See Malchert 2012, 177 with note 9. Indeed, we were not so convinced that the Hittite word karza(n) - (basically "(mass of) spun stuff") could have been related with the Luwian hieroglyph sign 314 (phonetic value /ka-/ or /ha-/) and its graphic representation (a wool basket rotated 90 degrees?). Cf. Melchert 1999, 128-130. The stands (or tables) frequently represented in the 1st millennium BC funerary stelae in the Syro-Anatolian area (see section 2.4.), are usually surmounted by horizontal bands topped by three loops. In fact, contrary to what Melchert claimed (Melchert 1999, 130), they cannot be interpreted as women's wool baskets nor as spinning bowls with internal or external fixed loops, just because in many cases it is so evident that loops actually represent breads and other food. Moreover these stands/tables are depicted even associated with men. Cf. Bonatz 2000a, 92. For this kind of baskets, see in general Barber 1991, 70-77. ${ }^{169}$ See, for instance, Haas 2003, 687: "Wollgegenstand". However, the presence of the determinative (SÍG) is not useful to support this suggestion. Perhaps it could simply indicate the leading thread to which white and red wool are plaited at.

${ }^{170}$ For the "doubling" vs. "draft-spinning" see in general Barber 1991, 47-48.

171 See Klengel and Klengel 2009.

172 On this matter, see Vigo 2010, 294, note 35, with previous bibliography.

173 KBo V 7, obv. 3, 13, 41. Cf. Rüster and Wilhelm 2012, 241.

174 See Vigo 2010, 291-293.

175 Singer 2008.

${ }^{176}$ Cf. Singer 2002, 52.

177 Compare in general Singer 2007, 169-170 with references.
} 
A presumed Hittite textile production, inferred from the analysis of textile tools found in archaeological contexts of 2nd millennium Anatolia, ${ }^{178}$ can hardly be confirmed by Hittite written sources. Although the following pattern is based solely on the evidence of the inventory texts and may not be representative, a region of textile production can be hypothesised in the Hittite Lower-Land (South Cappadocia) and in the Kizzuwatnean area (close to the Taurus mountain range, between Turkey and Syria). ${ }^{179}$ Unfortunately, we do not know if textiles named after cities or countries were always crafted there or followed the fashion of those places.

In order to acquire more knowledge about wool production in Anatolia during the Hittite Empire we should try to carefully join together and compare many text categories (cult and palace inventories, festivals, etc.), but it would require a long-term research. However, sifting through the texts we can suggest that wool was probably conveyed in warehouses (É tuppašs) ${ }^{180}$ by provincial administrators (LÚ'MEŠ AGRIG) together with livestock and dairy products. ${ }^{181}$ Then the wool was sent to various palaces and institutions as "compulsory gifts", ready to be converted into finished products. ${ }^{182}$ From another palace inventory we are informed that a considerable amount of wool was assigned to administrators, some identified by their place of residence or storehouses of the kingdom. In this case the type of colour is surprisingly never indicated, which could mean that this allotted wool was unprocessed, perhaps waiting for further processing. ${ }^{183} \mathrm{We}$ can say even less about any Hittite dyeing production, besides the aforementioned coloured products sent to Hatti from Cyprus, Ugarit or Lesbos. ${ }^{184}$ It is also difficult to ascertain if the dyed textiles cited in many text categories are generally the result of colouring processes or made of natural pigmentation. This is of course a matter of old debate and there is no need to insist on it. What can really be inferred from our cursory browsing through the Hittite texts, it is that in many cases dyeing could have been applied to yarns before being woven ("dyed-in-the-wool"). ${ }^{185}$ Regrettably, we cannot even assume that the terms ašara- and gaši $(\breve{s})$ - cited in the inventory texts KBo XVIII 199(+)KBo II 22 refer to the colours of unprocessed wool, ready to be treated by the women mentioned in these documents. ${ }^{186}$

Textiles are primarily quoted in the Hittite texts for their symbolic value. ${ }^{187}$ The scanty textile manufacturing processes we are able to draw from rituals and other religious texts are only faded

\footnotetext{
${ }_{178} \mathrm{Cf}$. the preceding section.

179 See Vigo 2010, 296, note 55. It is interesting to note that these areas actually reflect those of wool production during the Old Assyrian period. Cf. Wisti Lassen 2010a, 169, fig. 2.

${ }^{180}$ For É tuppaš as warehouse of bags/baskets (Gištuppaš), see already Otten 1988, 15; Mora 2006, 133; van den Hout 2010.

181 See, for example, Singer 1984, 109-110.

${ }^{182}$ Cf. Siegelová 1986, 213-245. We would tentatively interpret the amount of wool listed in category 5.5. ("IGI.DU.AEinkommen") of Siegelová (1986, 213-256) as unfinished products, but ready to be converted into finest garments, often

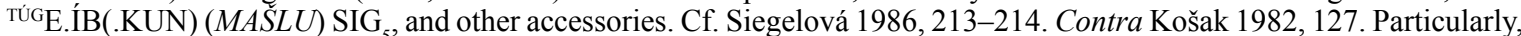
we consider the formula XX MA.NA/XX GÍN SÍG ŠÀ.BA XX GÍN MUG of KBo IX 90 and KBo IX 89 as "XX minas/ XX shekels of wool including XX minas/shekels of broken wool fibres (not suitable to be spun?)". Cf. Waetzoldt 1972, 56-57, also for MUG=mukku. Conversely, we did not find any convincing interpretation of the Sumerogram GiššU.TAG. GA of KUB XLII 48. See therefore Siegelová 1986, 242; 245, note 5. For the proposed reading SÜH in the same text, we would not stay with Siegelová (1986, 244 and note 4) either.

183 See Bo 6489 in Siegelová 1986, 324-327.

${ }^{184}$ See in particular Singer 2008, 29-31.

185 The best example is provided by the palace inventories that list incoming unprocessed wool of different colours (red, blue, green and yellow). Cf. Siegelová 1986, 90-91; 213-214.

186 Cf. Mora and Vigo 2012, 179-180.

${ }^{187}$ See the very useful list of attestations in Haas 2003, 638-690.
} 
mirrors of textile activities carried out in the 2nd millennium Anatolia and surrounding areas and they may just reflect regional (i.e. specific) features, more connected to the ritual praxis than to any textile activities. Ešduštaya and Papaya (Hurrian Hudena-Hudellura), the Hattian goddesses of fate (Gulšeš) spin in the underworld with spindles and distaffs the life of the Hittite kings and queens. ${ }^{188}$ Maybe they are also assisted by ritual weavers $(\mathrm{katra} / \mathrm{i} \text {-women })^{189}$ during birth rituals. ${ }^{190}$ Just like the Greek Moirai they controlled the thread of life of every mortal from birth to death. The textile tools they used have a symbolic value too. Spindles and distaffs are, in fact, used during incantations against impurity and diseases connected to sexuality. ${ }^{191}$ Spindle and distaff as symbols of femininity versus bow and arrows (the symbols of masculinity) are key tools used during martial ${ }^{192}$ and funerary rituals. ${ }^{193}$

Colours for cloths (or garments) also have a symbolic value. Despite the fact that the perception of colours differs greatly in cultures and it is therefore difficult to find exact equivalents, ${ }^{194}$ we know from Hittite texts that the predominant colours of textiles and garments were red, blue, green and purple. Black, white, red, blue and yellow colours have, indeed, a strong symbolic connotation. Natural coloured and dyed textiles are often used during rituals for their "chromotherapic properties" against diseases, evil and impurity. ${ }^{195}$

\subsection{Representational Evidence}

In the art of the ancient Near East, there exist representations of textiles that provide indications as to how and when particular kinds of textile were used and by whom.

Representation of textile technologies too may give specific information to better understand how textiles were produced. In this section, we analyse representations of spinning and spinning tools in Hittite Anatolia, then of weaving and weaving tools in the neighbouring regions that sent textile products to the centre of the Hittite kingdom.

Spindles and spindle whorls made of metal are some of the most interesting finds in late 3rd millennium BC funerary deposits at Alaca Höyük and Horoztepe; ${ }^{196}$ they are also quoted in texts dating back to the second half of 2 nd millennium $\mathrm{BC}^{197}$ and can be found in visual art of 2 nd and 1st millennium BC.

A Middle Bronze Age cylinder seal impression from Kültepe depicts a woman holding a spindle (Fig. 5.1). ${ }^{198}$ She has both hands raised, offering the spindle to the god seated in front of her behind an altar or a banquet/offerings table. More objects for spinning -spindles or distaffsare located behind the woman. A female figure on a seal impression from the North-Syrian site of Emar (modern Meskene) is holding a spindle in the same way (Fig. 5.2). In this 14th century BC example an altar/banquet table is present as well. ${ }^{199}$

\footnotetext{
188 See, in general, Haas 1994, 372-373.

189 Cf. Miller 2002, page 423 in particular.

190 See Beckman 1983, 118-119.

191 See, for example, the so-called "Paškuwatti Ritual" (CTH 406). Refer to Miller 2010 for the latest discussion on it.

192 E.g. the "First Soldiers' Oath". Cf. Oettinger 1967, 10-13.

193 Cf., for instance, Kassian et al. 2002, 98-99.

194 See recently Vigo 2010, 302, with previous bibliography.

195 Refer to Haas 2003, 638-649.

196 For these objects see section 2.2.

197 See section 2.3.

198 Teissier 1994, No. 348. For discussion see Bonatz 2000a, 79.

199 Beyer 2001, F7. Its style is similar to that of Mittani seals with local (Syrian) influences. But the comparison with
} 
Other seal impressions show female figures that appear to be holding spindles, although the damage does not permit us to be sure about the object represented. This is the case of a stamp seal impression from Hुattuša (Fig. 5.3), on which one can recognise a seated woman raising a cup and a spindle, while in front of her stands an offerings table. ${ }^{200}$

An interesting comparison for these scenes can be found in the iconography of a stele from Yağr ${ }^{201}$ Most scholars date this monument to the second half of the 2nd millennium $\mathrm{BC}$, although some doubts persist. ${ }^{202}$ The relief shows a banquet scene involving two figures, a man and woman seated at each side of a table: the man is poorly preserved, but one can see a raised arm holding a cup in a way identical to the woman on the other side, still clearly visible. This second figure was probably the most important and she is holding a mushroom-shaped item, likely to be a spindle, in her left hand.

In order to find further representations of spindles in the art of Anatolia, one has to look at the funerary memorial monuments dating back to the 1st millennium BC. The funerary art of this more recent period could have been influenced by that (unpreserved) produced in the 2nd millennium BC. ${ }^{203}$ These Iron Age stelae represent lone women, couples or three people sculpted in relief. On some of these monuments, women have attributes such as spindles, spindle whorls and distaffs (Figs 5.4-5.5):204 in some cases a single spindle with its whorl, in others spindle and distaff together. ${ }^{205}$

In all the representations, the spinning tools are always full of fibres (flax or wool) or yarn. Distaffs are represented as sticks; the fibres are

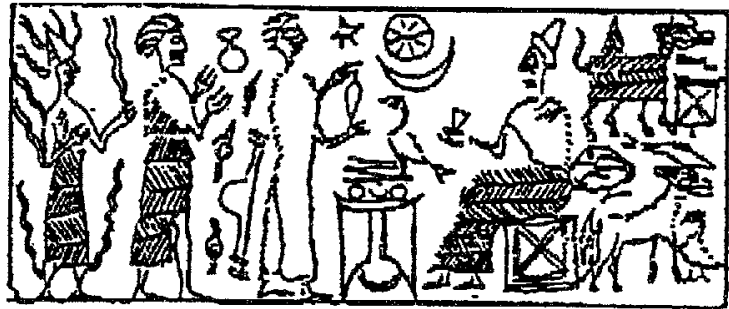

Fig. 5.1: Seal Impression. Kaně̌ (18th-17th centuries BC). Teissier 1994, No. 348.

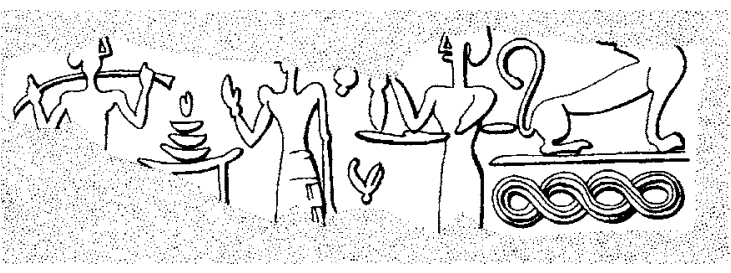

Fig. 5.2: Seal Impression. Emar (14th century BC). Beyer 2001, No. F7.

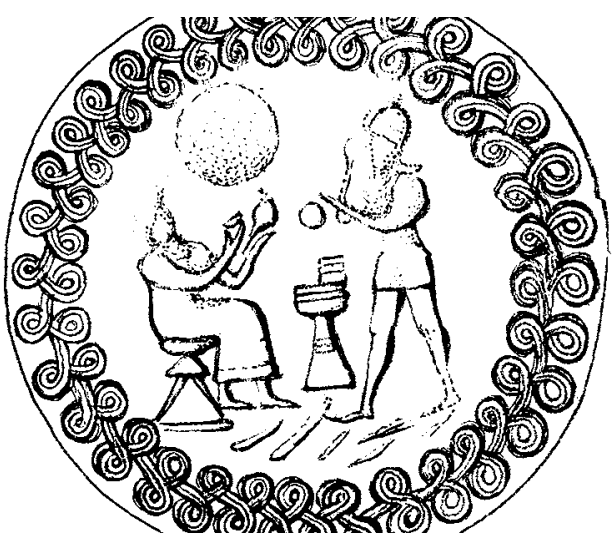

Fig. 5.3: Seal Impression. Hattuša (16th century BC). Boehmer and Güterbock 1987, No. 145d.

\footnotetext{
the Kültepe impression recalls the Anatolian iconography.

${ }^{200}$ Boehmer and Güterbock 1987, No. 145.

${ }^{201}$ First published by Crowfoot 1899, 40-45. See also Garstang 1929, 147-148, fig. 10; Bittel 1976, 201, fig. 230; Bonatz 2000a, 52-53. Cf. Darga 1992, 191, fig. 195.

${ }^{202}$ The few Anatolian (Luwian) hieroglyphic signs are difficult to date. See the remarks by Meriggi $(1975,263,264)$.

${ }^{203}$ Cf. Bonatz 2000b, 204 and note 44, 210. Orthmann 1971, 377-380.

${ }^{204}$ See Bonatz 2000a. Stelae with representations of spinning tools: C 21-25, 27, 33, 50-52, 59-61, 62, 68, 69.

${ }^{205}$ For a lone spindle see Bonatz 2000a, P1. 12, C22, for spindle and distaff see Fig. 5.5.
} 


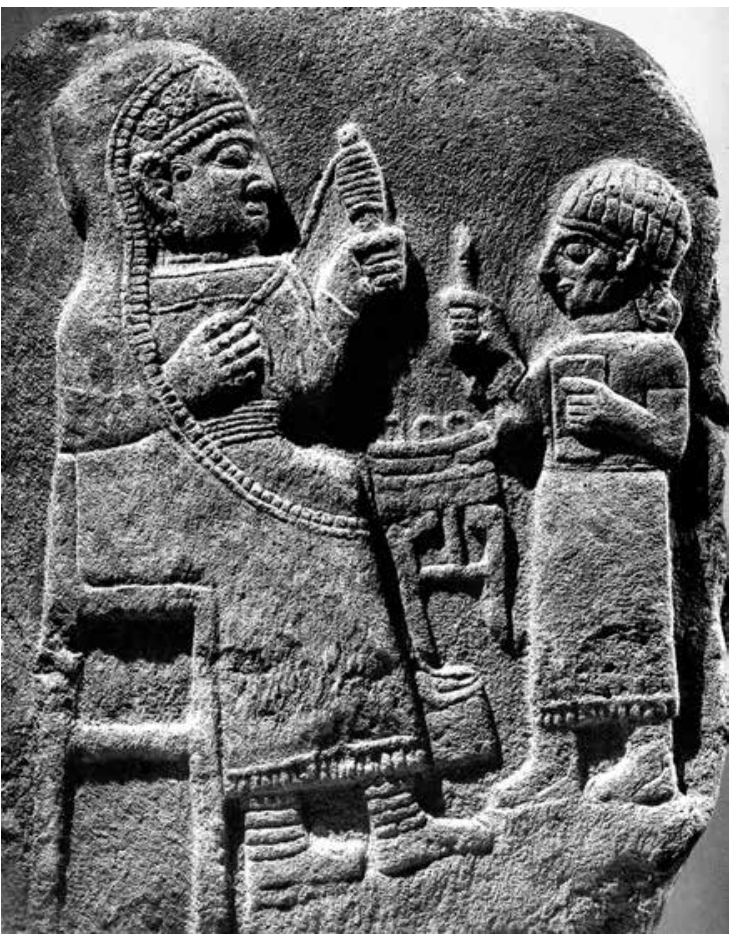

Fig. 5.4: Funerary stele. Maraş (8th century BC). Bittel 1976, fig. 313.

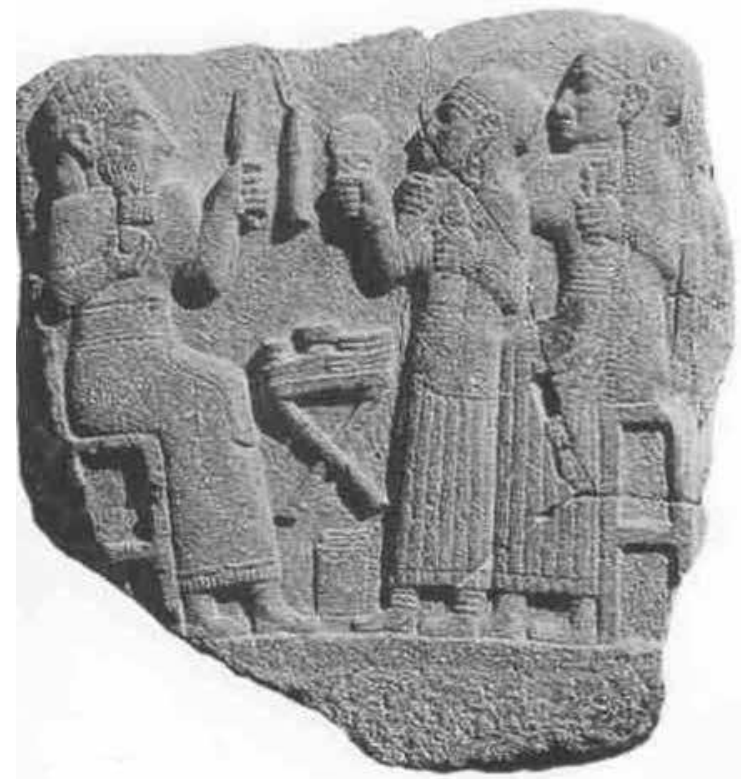

Fig. 5.5: Funerary stele. Maraş (8th century BC). Bonatz 2000a, Pl. 21, C60. wrapped tightly around them forming a sort of round ball. ${ }^{206}$ Spindles look similar, but the shape of the wrapped thread is, as expected, fusiform. ${ }^{207}$

In most representations it is impossible to distinguish the spindle whorl, even though one can imagine its location on the lower part of the spindle. ${ }^{208}$ When one finds spindles and distaffs together, the spindle always appears smaller, but when alone, it can be bigger. ${ }^{209}$

Even when together, these objects represent symbols not in use: women hold these in the same hand, as one can clearly observe on a funerary monument dating back to 9 th- 8 th centuries BC. (Fig. 5.5). On this monument, the banquet scene involves a seated man and woman and another woman standing. The woman on the chair rests an arm on the other's shoulder and in the left hand she holds a spindle and distaff. The standing woman, who might be the daughter of the deceased couple, raises a mirror in her right hand and again a spindle and distaff in her left. ${ }^{210}$

One of the stelae, coming from Maraş and dating to 8th century BC, shows a lady sitting with a spindle in one hand as a scribe stands in front of her (Fig. 5.4). ${ }^{211}$ This scene could be interpreted as a representation of a private moment: the lady of the house spinning. ${ }^{212}$ As stated by Dominik Bonatz, the smaller figures, depicted standing by the deceased, should be identified as descendants or heirs and not as servants. ${ }^{213}$ Comparisons are evident when one looks at a little stone relief from Susa, dated to

\footnotetext{
206 Cf. Fig. 5.5 and Bonatz 2000a, P1. 23, C68. Völling 2008, 95, figs 30-31.

${ }^{207}$ Cf. Bonatz 2000a, P1. 12, C22; Teissier 1994, No. 348. ${ }^{208}$ On a stone relief from Susa the spindle whorl is clearly visible located at the superior edge. Cf. Völling 2008, 93, fig. 27. On this relief see also infra.

${ }^{209}$ Cf. Bonatz 2000a, Pl. 18, C51; P1. 20, C59.

${ }^{210}$ Women holding spindles and distaffs in one hand were sculpted on Greek and Roman funerary monuments too. For a brief overview see Völling 2008, 95, note 378 and figures and Rova 2008. More details in Cottica and Rova 2006.

211 Bonatz 2000a, Pl. 18, C51.

212 Völling 2008, 93-94.

${ }^{213}$ Bonatz 2000b, 191.
} 
8th century BC, in which a woman seats with a spindle in her hands, while an attendant stands beside her. She holds the tool carefully in front of her, close to a banquet table. ${ }^{214}$ In both of these representations, it is uncertain whether this performance represents the quotidian action, a ritual or a symbol. Thus, in Anatolian art, one finds no definite representations of women spinning. An example from the neighbouring region is a well-known intarsia panel from Mari, dating back to the first half of the $3 \mathrm{rd}$ millennium BC, depicting a scene involving at least two spinning couples. ${ }^{215}$ Following a common interpretation ${ }^{216}$ the woman standing holds a distaff helping the seated and spinning woman (on her left). However, it is more likely that these women are not spinning but rather making skeins. The woman standing holds a big spindle, as the seated one unwinds yarn with both hands. ${ }^{217}$

Clearly and in conclusion, the spindle and distaff mark femininity in all the Hittite examples. Many works have already pointed to the interesting symbolic connotation of these instruments. ${ }^{218}$ As outlined in the previous section, spindles and distaffs symbolise womanhood in many Hittite texts. Thanks to visual art, one can add that mirrors symbolise femininity too. Visual representations and archaeological data confirm connections among spindles, distaffs and mirrors (e.g. in the grave goods of Horoztepe and Alaca Höyük) ${ }^{219}$ In visual art, these objects appear together in some burial stelae, dating to the 1 st millennium BC. ${ }^{220}$ These three items occasionally represent goddesses' regalia, ${ }^{221}$ inviting an interpretation of these women as priestesses. ${ }^{222}$ Ancient texts connect spinning to people's destinies and to particular goddesses involved in childbirth. ${ }^{223}$

The yarn has an evident connotation with the thread of life and as women create thread, they also create life in all its aspects. Spindle and distaff represented in art stress the femininity in two ways: first, they are symbols of textile economic activities typical of women who were the main manufacturers of textiles. Women spent their whole lives spinning, weaving and crafting clothes; this was true for every status. Second, spindle and distaff stress the most important role of females: the creation of life. This second point is particularly interesting because, as noted above, these symbols are often represented on funerary stelae of the Neo-Hittite period. Maybe the spinning tools carved on these monuments represents a hope for the afterlife because a woman can, in the same way, re-generate the life as she could create yarn (similar to the umbilical cord) and textiles. ${ }^{224}$ In

\footnotetext{
${ }^{214}$ Cf. Völling 2008, 93. She proposes that the lady is spinning very delicate yarn (appropriate for embroidery).

${ }^{215}$ Parrot 1961-1962, 178, figs 7-8.

${ }^{216}$ Völling 2008, 85-86, with references.

${ }^{217}$ Breniquet (2008, 292; Breniquet 2010,60) is in favour of this second interpretation.

218 Recently, Rova 2008; Cottica and Rova 2006.

${ }^{219}$ For the first see Özgüç and Akok 1958, 44; Pl. VII, 1. For the second Košay 1951, tomb L.

${ }^{220}$ For example, Bonatz 2000a, P1. 13, C27, P1. 19, C53, P1. 21, C60.

${ }^{221}$ Ninatta and Kulitta, servants of Šauška, holding mirrors on the relief of Yazilikaya (see Bittel 1975, Pl. 22). Kubaba on a Karkemiš relief holds a mirror and probably a distaff (see Bittel 1976, 254, fig. 289). With regard to this, the representation of a figure with a spindle in one hand and a mirror in the other on the Hasanlu gold bowl is particularly interesting. Cf. Winter 1989, 101, fig. 14. This female divine figure seated on a lion has been associated with Kubaba, but lions, mirrors and spindles are attributes of the goddess Ištar/Šauška too.

${ }^{222}$ Cf. Yakar and Taffet 2007, 782.

${ }^{223}$ On the metaphorical meaning of spinning and weaving in other cultures see recently the bibliography offered in Michel and Nosch 2010b, x, note 35. For Lamaštu amulets with a spindle see Wiggermann 2000; Farber 1980-1983.

${ }^{224}$ The connection between the thread of life and the umbilical cord is self-evident and has been identified by anthropologists and psychoanalysts in many cultures, ancient and modern. On this topic see the still very interesting paper by Róheim 1948. Although these suggestions are very intriguing, the application of these models of analysis in the field of the Ancient Near East requires further studies.
} 
some way, these representations provide a glimpse into the activities of the past life and a hope for a new one. The archaeological data provided in previous paragraphs, by underlining the presence of a huge number of spindle whorls in funerary contexts, could confirm the two hypotheses.

In the case of spindle whorls, one deals with items that were certainly used in daily life. In that of metal spindles in rich graves, scholars are not so sure. Their inclusion in funerary deposits seems not to depend on their use, but because they recall crafting activities as well as the femininity of the buried person. Otherwise, they can represent the hope for the pursuing of creation activities in the future. ${ }^{225}$ They could also be items not used for spinning, but to perform rituals.

Once spun, the yarn is ready to be woven. Iconography could help by enlightening us on the nature of ancient looms, hence providing us with information about textile production.

Illustrations of looms appear on early Mesopotamian seals and ceramic vessels and on Egyptian wall paintings and tomb models. ${ }^{226}$ These provide important documentary evidence that confirms the archaeological record and contributes to our understanding of loom construction in the ancient Near East and Egypt. The specific situation for Hittite Anatolia is different. In the total lack of such representations, archaeological finds and comparisons with images coming from other areas and periods help to determine the nature of looms used in Anatolia. ${ }^{227}$

As already pointed out, while the quotidian weaving in Anatolia and in the ancient Near East was generally done by women, on the contrary, some stages of textile production were probably entrusted to men. This is because some processes were hard and dangerous for children who were certainly spending the day with their mothers. ${ }^{228}$ Ritual weavers were also women, but the craftsmen entrusted by the palace to weave precious textiles appear to be mainly males. ${ }^{229}$ In ancient Near Eastern iconography, although seldom, one finds male weavers or men involved in other phases of the textile production. ${ }^{230} \mathrm{~A}$ procession of a ceremony involving the queen is reproduced on an interesting Urartian belt that presents a seated male beating a finished rug in a corner (Fig. 5.6). ${ }^{231}$

\section{Textile Use in Anatolia of 2nd millennium BC and in Neighbouring Areas}

\subsection{Archaeological Finds}

The study of textile remains is crucial for a comparative analysis linking archaeological, epigraphic and iconographical data.

Textile remains found in funerary and non-funerary contexts are considered here separately, focusing on those dating to the 2 nd millennium $\mathrm{BC}$, with references to previous periods.

The first example of non-funerary context dates to the Old Assyrian colony period in Anatolia (19th-18th centuries BC). A number of samples of fabric impressions were identified on the back

\footnotetext{
225 Barber 1994, 207-210.

${ }^{226}$ For these Early Mesopotamian seals and seal impressions reproducing weaving and the preparation of the warp, see Amiet 1972, Nos. 673, 674. For representations of different kinds of loom see Breniquet 2008, figs 84-91, Breniquet 2010, 61-62 and Fig. 4.7. For Egyptian tomb models see El-Shahawy 2005, 136, No. 84, Pritchard 1969, No. 142. For Egyptian paintings reproducing looms see Pritchard 1969, No. 143.

${ }^{227}$ For the vertical loom in Anatolia see section 2.2. For an interesting overview on Early Bronze Age Mesopotamia, see Breniquet 2008 and Breniquet 2010, 58 and fig. 4.2. Examples dating to the mid. 1st millennium BC Aegean area: Völling 2008, 145, fig. 54; Burke 2010, 106, fig. 52.

${ }^{228}$ On characteristics of women's work, so to conciliate children care, see anthropologist J. Brown, quoted in Barber 1994, 29-30.

${ }^{229}$ See Vigo in section 2.3 .

${ }^{230}$ In Amiet 1972, No. 674 weavers' sex is not clear. Other examples proposed by Breniquet $(2010,63)$ are still uncertain.

${ }^{231}$ Ziffer 2002, 647, fig. 4.
} 

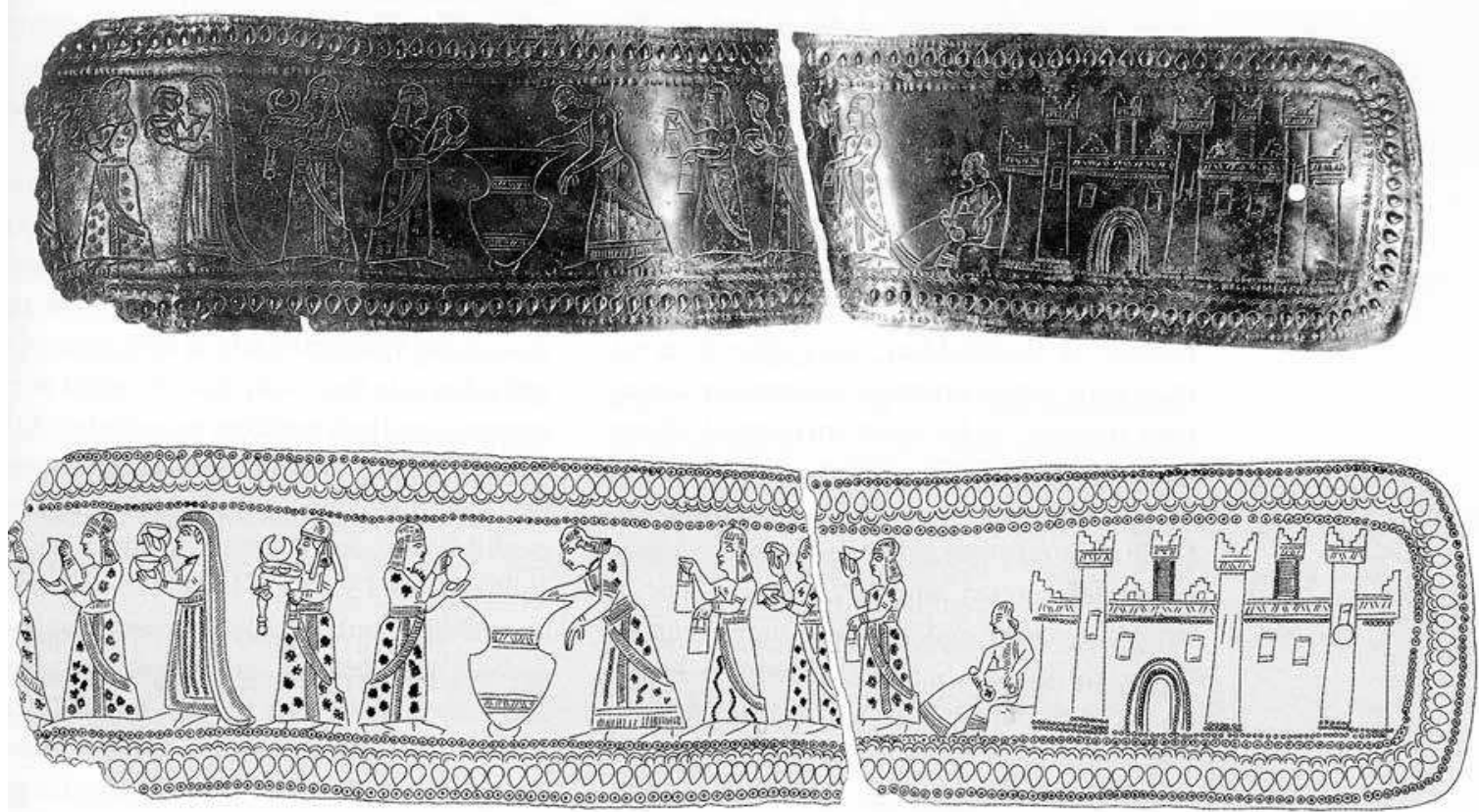

Fig. 5.6: Urartian belt. Detail of attendants of the Queen (8th century BC). Ziffer 2002, fig. 4.

of a number of bullae of Kaneš/Kültepe. ${ }^{232}$ Although the context of the discovery is often uncertain, Veenhof suggests that the clay sealings could have been used to seal containers such as bags sacks or clothes, travelling along the trade routes between Aššur and Cappadocia. ${ }^{233}$ A selection of these textile bags contained neither food nor other kinds of goods but rather tablets. This evidence adds another element to the interpretation of textiles use: bags, sacks or textile containers could have been used not only in the trade of goods but also in the transportation of tablets. ${ }^{234}$

As far as the fabric imprints on a number of seal impressions are concerned, ${ }^{235}$ it may be suggested that the seals were rolled over pieces of fabric. The use of fabrics as support in various activities would then represent a new element overlooked so far by analysis based on textual data or archaeological investigations. ${ }^{236}$

Examples of textiles from Kaman-Kale Hüyük also date to the Old-Assyrian colony period in Cappadocia. They were found in Room 150 (Kaman Phase IIIc). Most of these charred cloth pieces consisted of bundles of threads; $;^{237}$ but among them is a small fragment of fabric with decorative motifs. In the first case we deal with loose thread where warp and weft are not definable, while the second example quite clearly presents a weaving structure known as "Sumac-technique". ${ }^{238}$

\footnotetext{
${ }^{232}$ As confirmed by cloth impressions on the back of bullae Kt.87/k328, Kt.87/k329. See Özguç and Tunca 2001 , P1. 92. Völling 2008, $240 \mathrm{FO}(59)$.

233 Veenhof 1972.

234 Veenhof 1972, 28; Veenhof 1997.

${ }^{235}$ Cf. several seal impressions on cretulae among those published by Özguç and Tunca 2001. For example, P1. 78 (St. 46).

236 Völling 2008, 240 FO(59).

${ }^{237}$ Fairbairn 2004, 109, Pl. 118, fig. 3.

${ }^{238}$ Fairbairn 2004, 109, Pl. 118, fig. 4. Völling 2008, 240-241 FO(60). For details on this technique, see Völling $2008,293-294$.
} 
According to Fairbairn, given the context, the charred fragments may have been part of bags used to store grains or belonging to the clothing of the inhabitants. ${ }^{239}$ The second example is the oldest proof of decorative technique on fabric. According to the excavator, it could belong to a textile imported from Assyria to Cappadocia. ${ }^{240}$ This finding suggests that in Anatolia, at the beginning of the 2 nd millennium $\mathrm{BC}$, there existed richly decorated fabrics. They were produced through different weaving techniques, embroidered with golden threads, overlaid with beads or probably decorative plaques, all of which contributed to the creation of different motifs. ${ }^{241}$

The site of Acemhüyük also provides evidence of textiles in Anatolia at the beginning of 2nd millennium BC. Three stripes of one fabric, unfortunately extremely burnt, were discovered in the Sarikaya palace. ${ }^{242}$ It is interesting to note that some of these pieces were decorated with faïence beads and golden threads. They were probably part of a garment, enriched with the first evidence of a technique of decoration similar to medieval brocade.

It is important here to include some Anatolian funerary contexts, even if they exceed the chronological span of our analysis. Their peculiarity is the presence of well preserved textile remains with evidence of decorations and traces of colours.

In a funerary deposition of Alişar Hüyük, dating to the mid. 3rd millennium BC (Burial e X14), archaeologists found some fragments of fabric stuck to skin and bones. ${ }^{243}$ Microscope analysis has identified traces of dark brown and yellow colours, suggesting that this may not be a shroud but instead a garment with a specific meaning. ${ }^{244}$ According to this interpretation, this garment could have actually been worn by the deceased or used to wrap the body.

The use of valuable fabrics, often dyed with a symbolic value in connection with the funerary context, implies that garments and cloths were generally considered precious goods, as well as bearers of meanings.

Another remarkable and recently published find comes from the Royal Tomb of Arslantepe, dating to the beginning of the 3rd millennium BC. ${ }^{245}$ The Royal Tomb is located in an isolated area and consists of a circular pit with a cist grave surrounded by stones. A male body was buried in the cist with a rich funerary deposit (two necklaces, a calcite vessel and 14 ceramic pots or jars). The body and a selection of grave-goods were placed on a wooden surface upon which were identified many traces of fibres, so abundant that the whole platform might have been originally covered by a sheet. Textile fragments were discovered near the shoulder and the left tibia of the body, others underneath the two necklaces suggesting that this fabric might have been used as a shroud or a mortuary dress. The deceased was not only decorated with jewels but also with precious fabrics, which, according to the archaeologists, were wrapped around the body and the grave-goods. ${ }^{246}$ The presence of two adolescents' skeletons on top of stones covering the cist indicates a high social status of the deceased. A boy and a girl lay in an unusual position, both wearing a copper pin, two spirals in the hair and a diadem. They were probably also wearing a garment and a veil, as

\footnotetext{
${ }^{239}$ Fairbairn 2004, 109, 114.

${ }^{240}$ Fairbairn 2004, 115.

${ }^{241}$ These embroidered clothes are not attested in Old Assyrian texts, although they are quoted in texts from Mari according to Rouault 1977a, No. 6; Rouault 1977b, 151 (for embroidery or decorative applications similar to sequins, 11. 40-46).

${ }^{242}$ Refer to Völling 2008, 241, with previous bibliography.

${ }^{243}$ Völling 2008, 238-239, FO(57).

${ }^{244}$ Fogelberg and Kendall 1937, 334-335 and fig. 60.

${ }^{245}$ Frangipane et al. 2009, 17-20, fig. 14-15.

${ }^{246}$ Frangipane et al. 2009, 18.
} 
suggested by the cloth fragments under the boy's diadem and others around the pins. ${ }^{247}$ Two more female skeletons were located at the feet of the first couple. According to the position in the grave, they appear to have been of a lower social status.

Up to now, there have been no textile remains recorded for 2 nd millennium funerary contexts in Anatolia. For the neighbouring area, it is important to recall the cases of Jericho in the Palestinian region and Tell el Sa'idīyeh in Jordan. ${ }^{248}$

The discovery of the Royal Tomb in Qatna is crucial for the comparison of funerary contexts in the Syrian area. ${ }^{249}$ The textile remains brought to light in the Qatna Tomb come from different contexts and are located in different areas of the burial complex.

Two main groups of fabric remains will be investigated here. The first group deals with the remains identified through microscopic analysis of sediment samples found in many spots in many areas within the Royal Tomb. Traces of textiles were recorded, for example, in main Chamber (1), in Chamber 3-4 (on the floor), ${ }^{250}$ along with fragments that show traces of purple dye. ${ }^{251}$ Belonging to this group are fabric remains found inside the sarcophagus in Chamber 4, on the wood platform in the North-East corner of Chamber 1 along with a number of fragments in advanced state of mineralization, which were found attached to beads and golden objects. ${ }^{252}$

The second group of textiles encompasses a relevant number of well-preserved pieces found in deposits on a table in Chamber $4 .{ }^{253}$ These remains show different levels and folds in the fabric stratification. In particular, they showed many coloured fragments with refined decorations, indicating that weavers were highly skilled in their craft. ${ }^{254}$ This decoration involves the overlay of fabrics.

The findings in the Qatna Tomb are absolutely striking in their state of preservation and in their manufacture. They emphasise the prestige and luxury of these funerary contexts.

\subsection{Written Sources (Part Two: The Use of Textiles and Garments)}

Textiles as finished products are listed among luxury goods in many Hittite text categories. Since it is impossible here to refer to a huge variety of clothes mentioned in the Hittite documentation, we limit our survey to significant samples in an interdisciplinary perspective.

Textiles and garments were exchanged between royal courts. In a letter sent by the Hittite king Suppiluliuma I to the pharaoh Amenhotep IV, found in the el-Amarna archives, the sovereign of Hatti tried to come to an agreement with the newly enthroned king of Egypt. In order to ease the process, Šuppiluliuma sent to his "brother" wonderful golden statues, embellished with lapis lazuli. Among the magnificent luxury goods that symbolise a new friendship after the death of the previous pharaoh, huzzi-cloths are listed. ${ }^{255}$ In a similar way, the king Tušratta of Mittani, a neighbouring land locatable to the modern Khābūr valley (North-Eastern Syria), needed to enhance the agreement he

\footnotetext{
${ }^{247}$ Frangipane et al. 2009, 19 and fig. 19.

${ }^{248}$ Crowfoot 1960; Crowfoot 1965; Pritchard 1980.

249 Al-Maqdissi et al. 2002, 189-218.

${ }^{250}$ Reifarth and Drewello 2011, 469-482.

${ }^{251}$ James et al. 2009, 1109-1118; Reifarth and Baccelli 2009, 216-219; James et al. 2011, 449-468.

${ }^{252}$ Reifarth and Drewello 2011, 478, Pl. 2.

253 Dohmann-Pfälzner and Pfälzner 2011, 483-485.

${ }^{254}$ Reifarth 2011, 499.

${ }^{255}$ EA 41, 35-36. The huzzi-cloth may refer to a precious Hurrian fabric.
} 
came to with the father (Amenhotep III) of the heir to the throne (Amenhotep IV). ${ }^{256}$ Hence, he sent to the pharaoh a Hurrian tunic (TÚG.GÚ.È.A HURRI) and a precious over-garment (TÚGBAR.DUL). ${ }^{257}$ The "Hurrian shirt/tunic" seems to be one of the most fashionable garments among the ancient Near Eastern sovereigns, as also testified by its occurrence in the Hittite palace inventories. ${ }^{258}$ Among the subjugated persons that appear on the wall paintings of the Men-kheper-Re-seeb's tomb in Thebes (Egypt), two have been identified as the "Prince of Hatti" and the "Prince of Tunip", respectively. ${ }^{259}$ According to Goetze the latter is wearing what can be considered a Hurrian shirt. ${ }^{260}$ The TÚG BAR.DUL ("cloak"/"mantle"?) forms part of the gods' clothing set in Mesopotamian texts, also in the Akkadian form kusitu. ${ }^{261}$ It is mentioned in a letter between the pharaoh and the king of Cyprus (Alašiya) ${ }^{262}$ and in an Egyptian inventory of goods stored in the treasury, from the el-Amarna archive. ${ }^{263}$ The strange form ${ }^{\text {TÚG }} k u s ̌ i s ̌ i(-) D U L$ quoted in a Hittite palace inventory together with minas and shekels of gold with copper as tribute, may perhaps indicate that the Hittite (TÚG) $k u s ̌ i s ̌ i-$ is a loan word from the Akkadian kusitu ${ }^{264}$ The logogram ${ }^{[T U ́ G]}$ BAR.DUL is attested only twice in a fragmentary palace inventory. ${ }^{265}$ Sifting through the Hittite documentation, we can assume that the same over garment is mentioned several times in different text categories by means of the logogram ${ }^{\text {TÚG }}$ BAR. "TE". ${ }^{266}$ According to Goetze the Hittite word for TÚGBAR.DUL/"TE" should be a neuter gender noun because of ku-e TƯGBAR."TE"MEš in KUB VII 8, col. III 16. ${ }^{267}$ This can be the case of the $i$-stem noun kušiši-

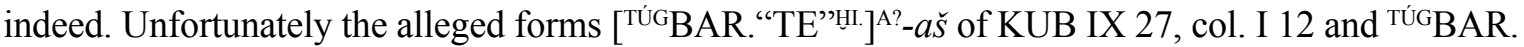
"TE"-eš of KUB XXXV 133, col. I 21, although not clear at all, raise some doubts. Apparently, the "ÚGBAR."TE" and the kušiši-garments appear in similar contexts. The BAR."TE"MEš are frequently mentioned in palace inventories that list precious garments assigned to individuals and palace officers ${ }^{268}$ or as luxury incoming clothes from different places and persons as tributes. ${ }^{269}$ They usually come in blue purple or green-blue purple colours. ${ }^{270}$ They are almost always listed together with shoes ( ${ }^{\mathrm{KUŠ}} \mathrm{E}$. SIR ${ }^{\text {HI.AA }}$, leggings/gaiters or underclothes (TÚG GAD.DAM MEŠ/HI.A or ${ }^{\dagger} k a t t a m a-{ }^{271}$ ), shirts (TÚG. GÚ.È.A), belts/waist-bands ( ${ }^{T U ́ G} E . I ́ B$ ) ${ }^{272}$ and head-covers ( (ỨGSAG.DUL), forming the main elements of a complete dress. This kind of over garment is spread over a patient during a ritual:

\footnotetext{
${ }^{256}$ EA 27, rev. 110-111.

257 The name denotes a ready-to-wear garment: "garment (túg) which covers ( $d u l)$ the (out)side (bar)". Perhaps the logogram defines a kind of mantle.

${ }^{258}$ See Siegelová 1986, 651. This "Hurrian shirt" must be a more ornate variation of the simple shirt (TÚG.GÚ.È.A). It may be embroidered or trimmed with gold or silver. A good quality $\left(\mathrm{SIG}_{5}\right)$ shirt seems not being an expensive item though (three shekels). Cf. "Hittite Laws": § 182. Hoffner 1997, 145-146.

${ }^{259}$ Cf. Pritchard 1969, 15, fig. 45; 255, No. 45. Cf. the following section (3.3.).

${ }^{260}$ Goetze 1955, 54. Cf. Pritchard 1951, 39, fig. B; 40. Pritchard 1969, fig. 45; 255, No. 45.

${ }^{261} \mathrm{CAD}$ "K”, $586 \mathrm{~h}, 587$ 3'.

${ }^{262}$ EA 34, 23.

${ }^{263}$ EA 14, col. III 27.

${ }^{264}$ Cf. already Goetze 1947a, 178-179; Goetze 1955, 57.

${ }^{265}$ KBo XVIII 175, col. VI 1-2. In the same text we surprisingly find also BAR."TE” HI.HI (col. II 5). The result of this provisional search is based on a CHD files survey (January 2013).

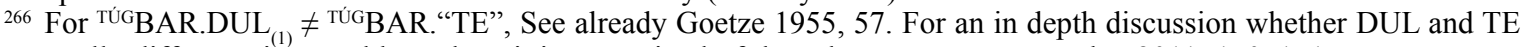
are really different signs and how the Hittite conceived of these logograms, see Weeden 2011, 170-171.

${ }^{267}$ Goetze 1955, 57, n. 80.

${ }^{268}$ E.g. KUB XLII 106.

${ }^{269}$ E.g. NBC 3842.

${ }^{270}$ Here we follow the colour designations recently sketched by Singer $(2008,23-24)$.

${ }^{271}$ As tentatively suggested by Weeden $(2011,226-227)$.

${ }^{272}$ Cf. Weeden 2011, 377, 470. See below for further interpretations.
} 
"The cloaks ( ${ }^{\mathrm{TU} G \mathrm{~B}} \mathrm{BAR}$."TE”MEŠ) or the tunics which are lying on the soldier bread he will spread out (each) night [...] Once more they spread a bed for him down in front of the table. They also spread out below for him the cloaks or tunics which have been lying upon the soldier bread. The patient lies down, (to see) if he will see in a dream the goddess (Uliliyašši) in her body; she will go to him and sleep with him."273

It is also part of the festive garments to dress up statues of gods; $; 27$ it is even worn by the kingsubstitute during a ritual. ${ }^{275}$ The BAR."TE"MEŠ are also "presented", together with the garments mentioned above, to determine the exact aspect of a situation which has caused a deity's anger. ${ }^{276}$

The kušiši-garments are used to spread paths for gods:

"For you (plur.) I have spread paths with a swath ( $\left.{ }^{\mathrm{TU} G} \mathrm{kurešnit}\right)^{277}$ of $a \mathrm{k}$. ( ${ }^{\mathrm{TU} G} \mathrm{kušišiyaš)",278} \mathrm{"Over} \mathrm{the}$ paths (made) of fine oil and honey he spread out a piece of cloth/a swath ( ${ }^{\mathrm{Tu} G} \mathrm{kureššar}$ ) from the soldier bread below, saying as follows: "O Storm-god of Kuliwišna, keep walking on a path (made) of a swath ( ${ }^{\mathrm{TU} G}$ kurešnaš) of a k.-cloth ( ${ }^{\mathrm{TU} G} \mathrm{kušišiyaš)!} \mathrm{And} \mathrm{for} \mathrm{you,} \mathrm{may} \mathrm{your} \mathrm{feet} \mathrm{not} \mathrm{trample} \mathrm{brushes} \mathrm{and} \mathrm{stones!} \mathrm{May}$ (the path) be smooth under your feet!'279

We find the kušiši-garment in a ritual against impurity that implies as Materia Magica soldier bread and other garments ${ }^{280}$ and in a funerary ritual. ${ }^{281}$

From a passage of the prayer of the king Arnuwanda I and Ašmunikal to the Sun-goddess of Arinna about the ravages of the Kaška people we can infer that kušiši-garments, though scarcely attested among the bare lists of tributes, were probably offered to deities in temples:

"The lands that were supplying you, O gods of heaven, with offering bread, libations, and tribute, from some of them the priests, the priestesses, the holy priests, the anointed, the musicians, and the singers had gone, from others they carried off the tribute and the ritual objects of the gods. From others they carried off the sun-discs and the lunulae of silver, gold, bronze and copper, the fine garments, the festive ones? ( ${ }^{\mathrm{TUG}} \mathrm{HIA}$ adupli), ${ }^{282}$ shirts/tunics of a k. (kušišiyaš), ${ }^{283}$ the offering bread and the libations of the Sungoddess of Arinna." 284

The kušiši-garment is poorly attested in the palace inventories, but it is always listed together with other festive-garments (TÚG NÍG.LÁM ${ }^{\mathrm{MEŠ}}$ ) like head-bands (lupan(n)i-) and kureššar. ${ }^{285}$ Beside the $k u s ̌ i s ̌ i^{286}$ these two items can form the royal dress of kings and queens. ${ }^{287}$

\footnotetext{
273 CTH 406 (Ritual of Paškuwatti against Impotence [or Homosexuality]): Excerpta $\S \S 12 ; 17$. We believe that cloaks are spread over "soldier bread" and then on the bed in which the patient lays in order to absorb virility and pass it to the patient himself.

${ }^{274}$ E.g. KBo XLVII 266+, col. I 7-8.

${ }^{275}$ KBo VII 21, 8'-10'.

${ }^{276}$ KUB XXII 70, obv. 10-12. Cf. Ünal 1978, 33; 84-85.

${ }^{277}$ For the word ${ }^{\mathrm{TU} G} \mathrm{k}$ kureššar- see below.

${ }^{278}$ KUB XV 34, col. I 40-41.

${ }^{279}$ CTH 329/330. Cf. Groddek 2007, 332-333.

${ }^{280}$ E.g. KBo XXIX 202+KBo XXXVIII 219, col. III 1-8. Cf. Groddek 1999, 34-35. See also KBo VII 29.

${ }^{281}$ KUB XXX 28(+)XXXIX 23, obv. 24-27.

${ }^{282}$ Siegelová $(1986,706)$ considers ADUPLI listed in the palace inventories as an Akkadogram. Contra Starke 1990, 207-208: aduplit- ("festive garment") as loan word from Akk. alutuplu (+ ${ }^{\circ}$ t) (KUB LVIII 33, col. III 26: aduplita nom./ acc. Plur.); but see, for instance, $a-t u$ - up-li-aš of KBo XXXIX 217, 5'.

${ }^{283}$ Following Singer's translation $(2002,41)$, we prefer to interpret it as a genitive singular instead of a comm. gender accusative plural of kušiši-. Contra Tischler (HEG "K", 674). Note also that it lacks of determinative TÚG.

${ }^{284}$ KUB XVII $21++$, col. II 14 '-17'.

${ }^{285}$ E.g. KUB XLII 14++; KUB XLII 55; KUB XLII 56.

${ }^{286}$ See the attestations in Goetze 1947a, 177.

${ }^{287}$ E.g. KUB XLII 98, col. I 10-12.
} 
The Hittite term (TÚG) kurě̌šar-, literally "cut of cloth", ${ }^{288}$ basically defines a piece of cloth used during rituals:

E.g. "She? sets $[$ the b(asket)] of "drawing $[$ the deity...] along the road" $[($ dow $)] n$. [...they wr(a)p] the red wool [...] She? spreads a cut of cloth [and then] she speaks as follow, [(cal)]ls the deceased [(by name:)] "May these reeds be [the br(idg)] $\mathrm{e}^{\text {? }}$ for you!»" 289

It can also indicate the veil worn by goddesses and queens in religious contexts. It is attested as a precious garment entrusted to high dignitaries of the Hittite court and itemized among other ritual clothes. ${ }^{290}$ We believe that both the kušiši-garment (hence cloak/mantle?) and this female cloth are represented in the Hittite rock reliefs. ${ }^{291}$

Based on this preliminary investigation of the Hittite textiles terminology, we would also

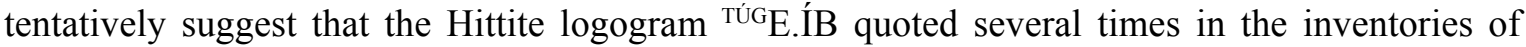
incoming items, ${ }^{292}$ could be represented as part of the dress of the well-known king/deity in the "King's Gate" relief of Hattuša. Looking at the belt that fastens that trimmed kilt ("ÚG'IB. LÁ? MAŠLU), ${ }^{293}$ the association with ${ }^{T U ́ G}$ E.ÍB.KUN seems plausible. Indeed this waist band/belt sometimes provided with a sort of tale (KUN) as the one in the relief, is occasionally mentioned in texts together with golden or bronze inlays and weapons as they were part of a special kit. ${ }^{294}$

As it has been outlined in this paper, there are no textile remains surviving from 2nd millennium funerary contexts in Anatolia. Nonetheless, Hittite funerary rituals refer to precious/festive garments (TÚGNÍG.LÁM ${ }^{\mathrm{MES}}$ ) offered to the statues which might represent the royal couple during the funeral:

"One?] man [puts] a bow [〈and $\rangle$ arrows] 〈in $\rangle$ his (i.e. statue of the deceased?) hand. But [if it is a wo]man (i.e. if the queen has died) [he puts] a distaff [and spindle 〈in〉 her hand.] And [they give?] to her precious/ festive garments." 295

or to preserve the purified bones of the deceased:

"〈They take $>$ a silver $\mathrm{hu}<\mathrm{p}>$ par-vessel (weighing) twenty minas and a half(?), filled with fine oil. They tak[e] out the bones with silver tongs? and put them into the fine oil in the $\mathrm{hu}<\mathrm{p}>\mathrm{par}-\mathrm{vessel}$. They take them out of the fine oil and lay them down on the linen kazzarnul-cloth. A fine cloth is laid under the linen cloth. When they finish gathering the bones, they wrap them in the linen and fine cloths." 296

This brief and selective survey on Hittite clothing aimed not only to show the use of textiles in different contexts but also to propose some key elements for further comparisons with the Hittite artistic production.

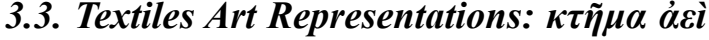

Textiles crafted in Anatolia or in the neighbouring areas were certainly used in many different ways. They were common in everyday life in the form of bags, clothes, bandages, bed clothes, but also

${ }^{288}$ Cf. HED "K”, 262; EDHIL, 494.

${ }^{289}$ KUB LX 87, rev.? 3'-10' with dupl. Cf. Kassian et al. 2002, 730-731.

${ }^{290}$ See the list of attestations in Siegelová 1986, 363-369. Cf. Goetze 1947a, 178.

${ }^{291}$ Refer to following section (3.3.). Cf. already Goetze 1947a, 178, n. 19; Goetze 1955, 57, n. 78.

292 E.g. KUB XLII 48.

${ }^{293}$ Cf. Goetze 1955, 56 also for the particular use of the verb :putal(l)iya/e- "put on light clothes". But see also CHD "P", 401-402. For trimmed kilt(?) (TUGǴB.LÁ? MAŠLU) together with waist bands/belts see KBo XVIII 181, obv. 5, 24.

${ }^{294}$ Compare the attestations in Goetze 1955, 55-56.

${ }^{295} \mathrm{KBo}$ XXV 184, col. II 60-62. Cf. Kassian et al. 2002, 98-99.

${ }^{296}$ KUB XXX 15+, obv. 3-8. Cf. Kassian et al. 2002, 260-261. 
tents. As known from texts quoted in the previous pages, textile products were often considered as luxury goods. Precious clothes were, hence, richly decorated and used for furniture, garments and gifts or given as tributes. Visual art is somewhat revealing on these uses of textiles in ancient Anatolia.

The most obvious use of fabric in representational art is the depiction of clothing. In the art of the ancient Near East clothes indicate civilization and power. ${ }^{297}$

Garments have the primary purpose to protect the body, but have also other important functions such as indicating social status. In all the time periods, the elite wear better quality clothing than lower classes. Unfortunately, common people rarely appear in art while the majority of information found in visual representations concerns garments of the elite or ritual clothes, as well as the wonderful pieces thought to be worn by gods.

The case of Hittite Anatolia is suggestive of this problem. Observing Hittite art we realize that the main purpose was always symbolic. Reliefs and seals dating to the 14th-13th centuries BC reproduced human figures identifiable with gods and goddesses, kings and their families. ${ }^{298}$ The garments worn by Hittite kings and queens on monuments and seals seem to be highly representative, in order to communicate immediately to the observer the power of the figure in front of him. ${ }^{299}$ Many Hittite reliefs represent the king. In some cases he dresses as a warrior, but most times he wears particular garments - a long tunic or mantle - which appear to be ceremonial. The attitude of the sovereign in this last case is similar to that of a priest (Fig. 5.7). The Hittite king is represented this way, for example, on two orthostats at Alaca Höyük, in two in Alalah, on two reliefs at Yazılıkaya, on the Sirkeli relief and on some seal impressions found in the Hittite capital and in other sites. ${ }^{300}$ In some other examples (such as the reliefs at Yazllıkaya, an ivory plaque from Megiddo, a gold and lapis lazuli tiny figure from Karkemiš and seal impressions from peripheral sites such as Emar), divine figures are dressed in the same way as the priest-king. ${ }^{301}$

The king wears a two-piece robe: a loose-fitting, short-sleeved garment that reaches to the feet, and a cloak with edges falling over both shoulders. In some cases there is a sort of pointed tail on the back. ${ }^{302}$ The hem of this mantle is often trimmed, although details are not clear. The king dressed in this way usually bears a round cap. In the example from Alaca Höyük (Fig. 5.7) though, he has the head and the back covered by a sort of long veil, probably fixed by a metal band. ${ }^{303}$

\footnotetext{
${ }^{297}$ It is important to remind that Enkidu in the epic of Gilgameš is metaphorically dressed once civilized (Bier 1995, 1582). Nakedness was specifically used to indicate prisoners, disgraced and humble people (for examples in seals, cf. Otto 2000, No. 434) or in fertility contexts (on naked women as symbol of fertility, see Mazzoni 2002; Pruss 2002). Significant exceptions where the heroes are naked, have also been encountered in visual representation in Anatolia (E.g. Kültepe seal impressions show this motif. See Teissier 1994, 161, 163-165).

${ }^{298}$ Reliefs dating to the 1st millennium BC, as those observed for the representation of spindles and distaff in section 2.4, will not be analysed here. For detailed description, see Özgen 1985. Moreover, we refer only occasionally to the garments worn by gods, leaving this topic for a future study.

${ }^{299}$ On this topic, see recently Bonatz 2007.

${ }^{300}$ Reliefs. Alaca Höyük: fig. 7. Yazılıkaya: Ehringhaus 2005, 25, figs 38, 44. Sirkeli: Ehringhaus 2005, 198, figs 175-176. Seals. Hattuša: Herbordt 2005, Nos. 317, 494; Herbordt et al. 2011, Nos. 39-42, 53.

${ }^{301}$ Cf. for Yaz1lıkaya Bittel 1976, fig. 234. For the Hittite ivory plaque from Megiddo see Loud 1939, Pl. 10F. For Karkemiš golden divine figures, cf. Bittel 1976, fig. 242. For Emar seals, Beyer 2001, Nos. A1, A7, A10, etc. On the problem of the identification of the figure surmounted by a winged sun, see Mora 2004, 446-447 with previous bibliography. Examples of images of actual priests performing rituals are encountered among the extremely interesting reliefs in Alaca Höyük. Cf. Bittel 1976, figs 212, 220, 222.

${ }^{302}$ Cf. Ehringhaus 2005, 25, fig. 38.

${ }^{303}$ See recently Vigo 2010, 310-315.
} 


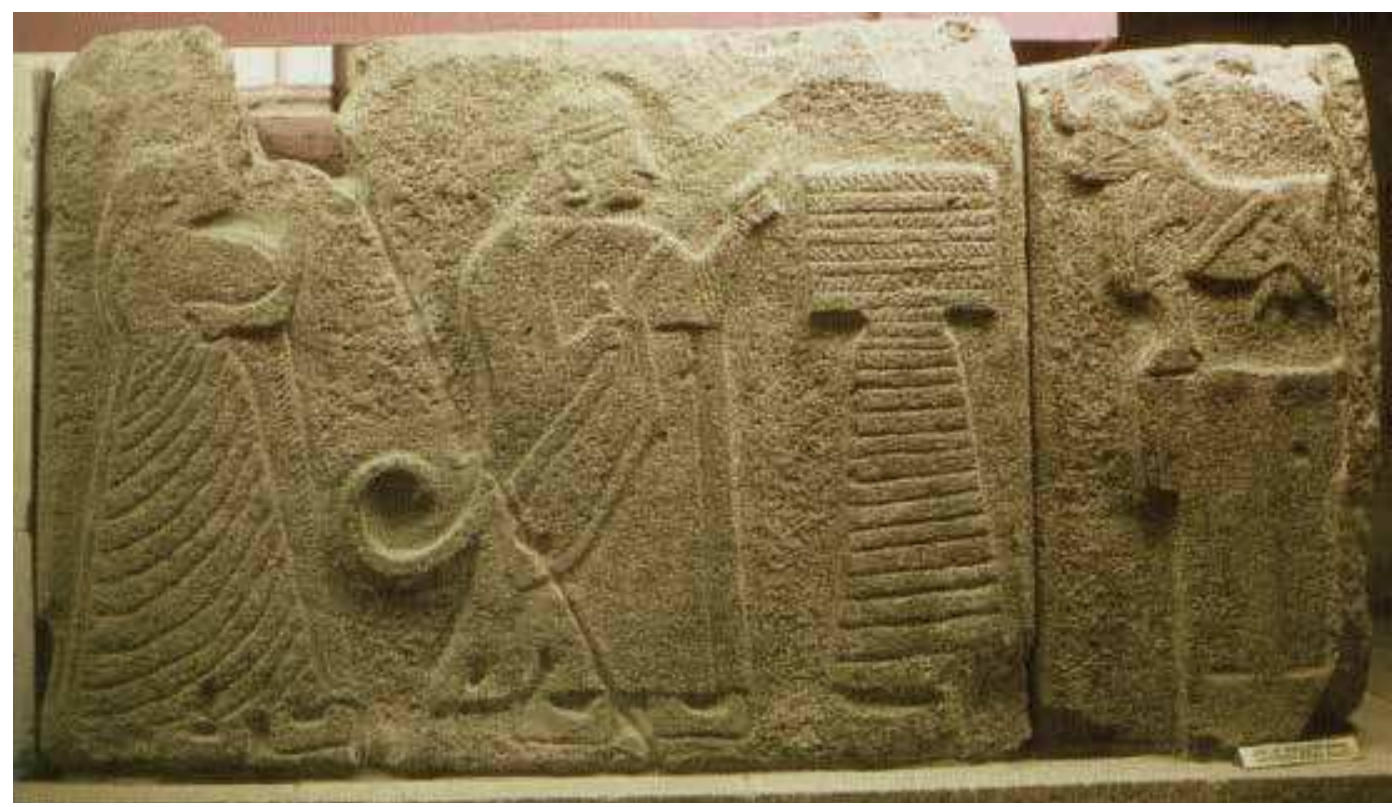

Fig. 5.7: Offering scene. King and Queen. Relieffrom Alaca Höyük (14th century BC). Ehringhaus 2005, fig. 3.

The king is represented as a divine warrior on seal impressions and on reliefs, such as two relief blocks from Temple 5 (Fig. 5.8) and from Chamber 2 in Boğazköy, the Hittite capital Hattuša (Fig. 5.9), and a rock relief in Firaktin. ${ }^{304}$ Princes are also represented as warriors, for example, on rock reliefs at Hanyeri and Hamide. ${ }^{305}$ In all these cases the royal figures wear a short kilt. On their head, they can wear a high, conical hat with multiple horns, but also a rounded cap as in the cases of Hanyeri and Hamide. Details of the kilt are not always clear, as exemplified in Fig. 5.9. In Fig. 5.8 the kilt is one piece, trimmed at the lower edge and worn with a thick belt, while in Firaktin, Hanyeri and Hamide's examples edges appear overlapping at the front.

The martial kilt worn by the male figure on the so-called King's Gate at Boğazköy is very short. ${ }^{306}$

This type presents an elongated edge overlapping the actual kilt in the front. The decorative pattern of bands of diagonal hatches and volutes that probably represented an actual garment is remarkable (Fig. 5.10). According to Elizabeth Barber, ${ }^{307}$ the cloth "must have been woven vertically on the loom - or the fringed edge woven separately and sewn on." Alternatively this could be a sort of belt/waist band as cautiously suggested above.

In Egyptian wall paintings representations of people identified as Hittites dressed in a short white kilt, or wearing a light tunic with a sort of kilt that probably was military attire are depicted

\footnotetext{
$\overline{304}$ Bittel 1976, fig. 198.

305 Bittel 1976, figs 201, 202. Ehringhaus 2005: 70-80, 107-112. Bonatz 2007, 120-123. See, recently, different interpretations by Simon 2012 .

${ }^{306}$ Bittel 1976, figs 267-268. Whether one should identify the figure as the divinized king or a god is a debated question. Similar kilts in Bittel 1976, figs 148, 262, 263.

${ }^{307}$ Barber 1991, 336-337.
} 


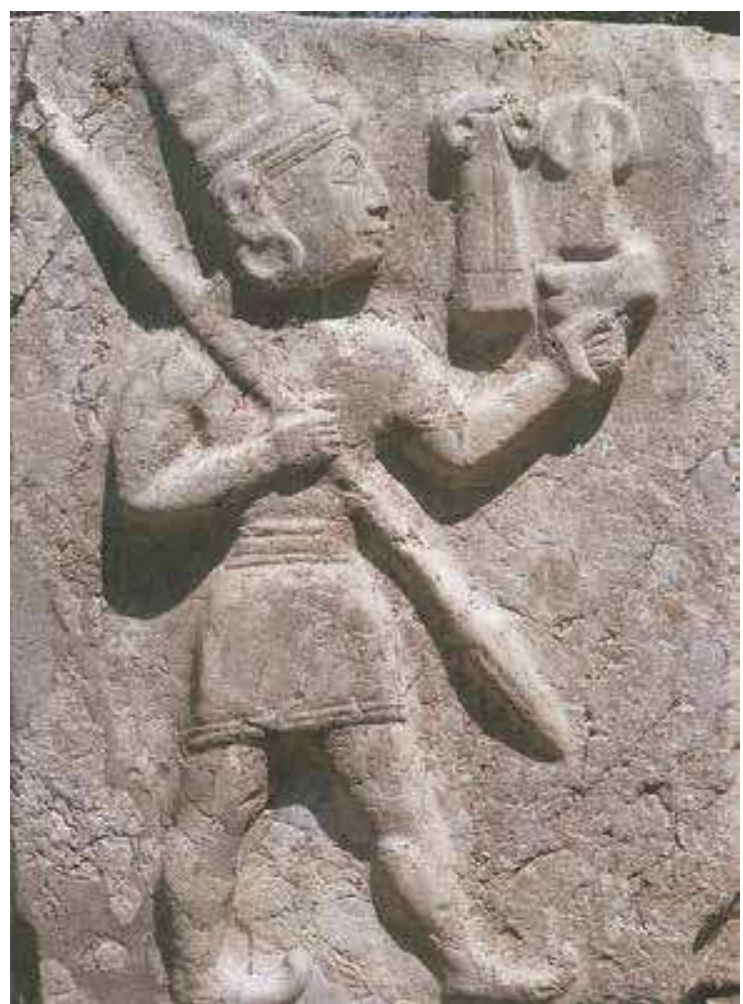

Fig. 5.8: King Tuhdaliya as a warrior. Neve 1993, fig. 100 .

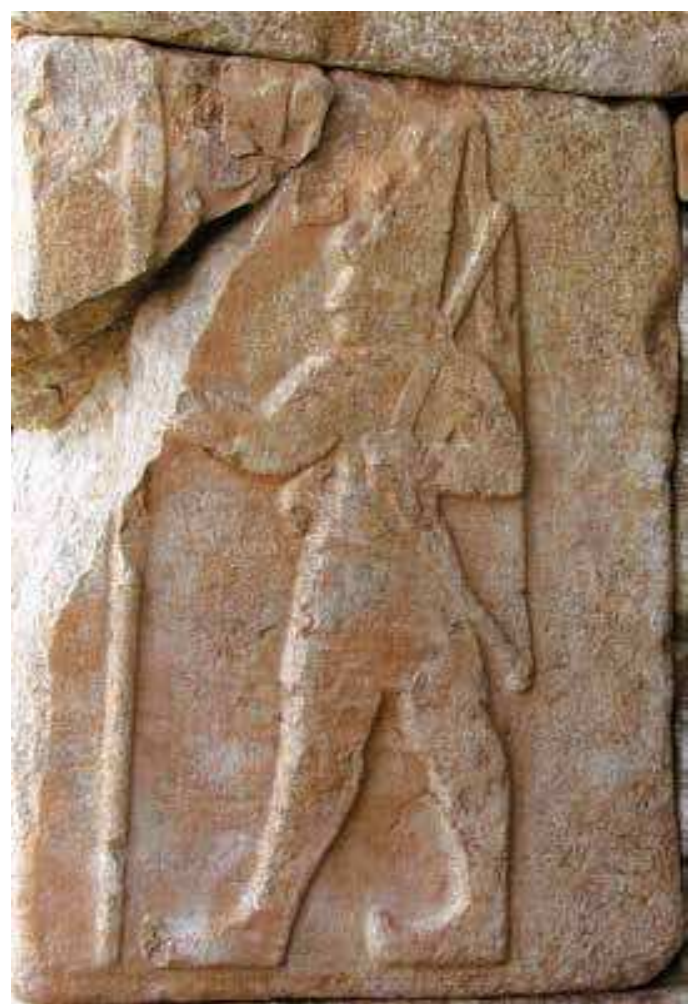

Fig. 5.9: Warrior, tentatively identified as king Suppiluliuma II. Relief from Hattuša-Südburg, Kammer 2 (13th century BC). Ehringhaus 2005, fig. 54.

(Fig. 5.12) ${ }^{308}$ On other Egyptian reliefs, Hittite soldiers wear long garments, wrapped around the body. ${ }^{309}$

On festive occasions Hittite men wore a longer tunic with long sleeves called Hurrian shirt, which is often mentioned in Hittite palace inventories, as reported above. A Hurrian shirt has been identified by Pritchard as the clothing of some figures (although indicated as Syrians) on Egyptian wall-paintings. ${ }^{310}$ In these paintings the shirt is white, but decorated in blue and red along the edges and with a long line running down the front. Other peculiar clothes were those worn by musicians and acrobats on reliefs at Alaca Höyük (Fig. 5.11). They look like kneelength long-sleeved robes with trimmed edges overlapped and shut in the front by means of a bow-belt. Also the clothing worn by a hunter on another Alaca relief is knee length, long sleeved and open at the front. ${ }^{311}$

\footnotetext{
$\overline{308}$ For representation of Hittites wearing short white kilt see Pritchard 1969, fig 45. For light tunic richly decorated and kilt see Pritchard 1969, fig. 35.

${ }^{309}$ Cf. Pritchard 1969, figs 7, 322, 333.

310 Pritchard 1951, 40. Pritchard 1969, figs 45, 46 (see also catalogue, 255, Nos. 45, 46). Cf. here section 3.2.

311 Bittel 1976, fig. 225.
} 


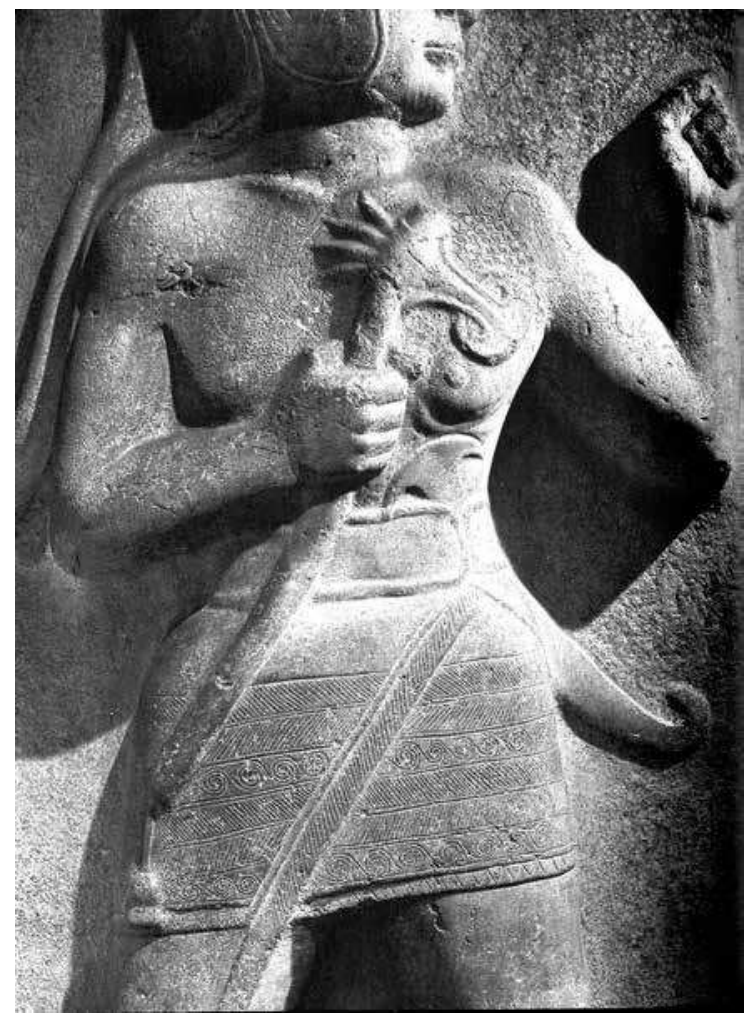

Fig. 5.10: Figure sculpted on "King's Gate" at Hattuša. Detail of the kilt. Bittel 1976, fig. 268.

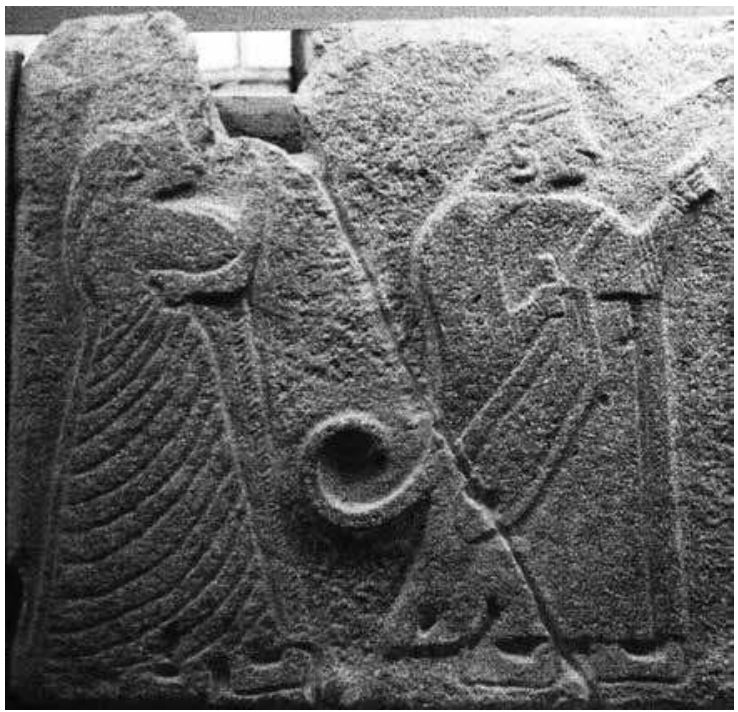

Fig. 5.11: Musicians and acrobats. Relief from Alaca Höyük (14th century BC). Ehringhaus 2005, fig. 3.

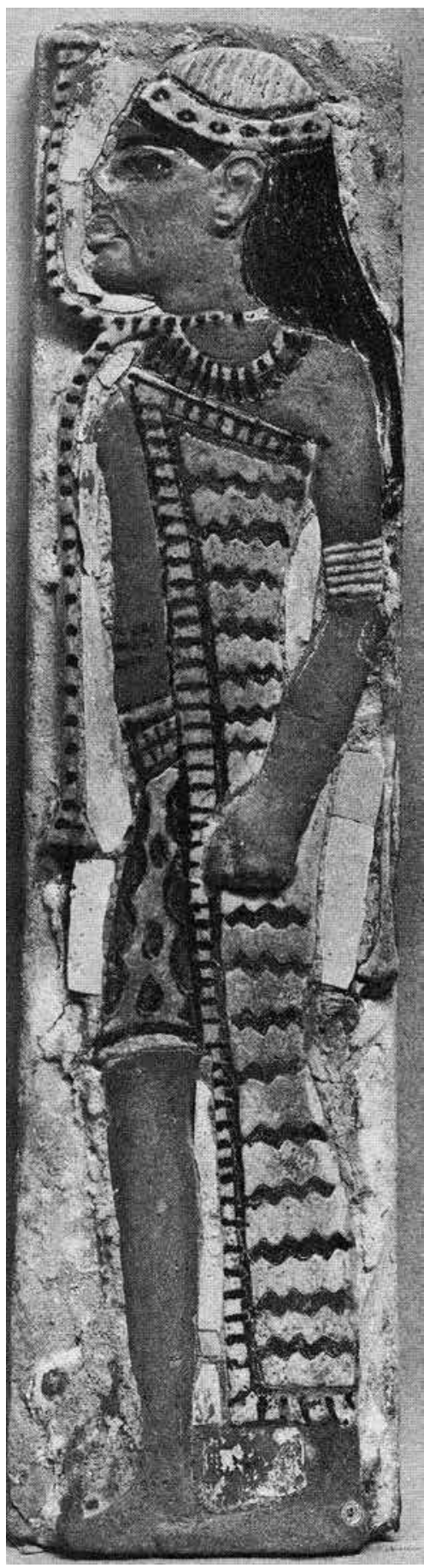

Fig. 5.12: Hittite prisoner on faiance tile (1195-1164 BC). Pritchard 1969, no. 35 . 
Women in ceremonial attire wore a tunic and a mantle-like veil. This could have been of different colours, as exemplified in Figs 5.15-5.17. Others wore a two-piece cloth similar to that of a goddess as in Fig. 5.13, i.e. a short-sleeved tunic with a round neckline and a veil covering the head. The tunic is not belted at the waist and reaches down to the ankles. The veil falls down the back of the goddess, but the damages does not allow a reconstruction of the top of the head.

Goddesses are represented with a long pleated skirt. Something similar is also worn by the queen performing a ritual together with the king in his priestly attire. ${ }^{312}$

Goddesses and queens sometimes wore a high pólos. ${ }^{313}$ In some examples, dating to the beginning of the 1 st millennium $\mathrm{BC}$, a long veil covers the pólos. ${ }^{314}$ As suggested in the previous section this long veil could tentatively be identified with the well attested kureššargarment.

We lack visual information about the colours of these garments. Of course, there are some indications of colours of textiles in the Hittite texts, but, even when it is possible to translate

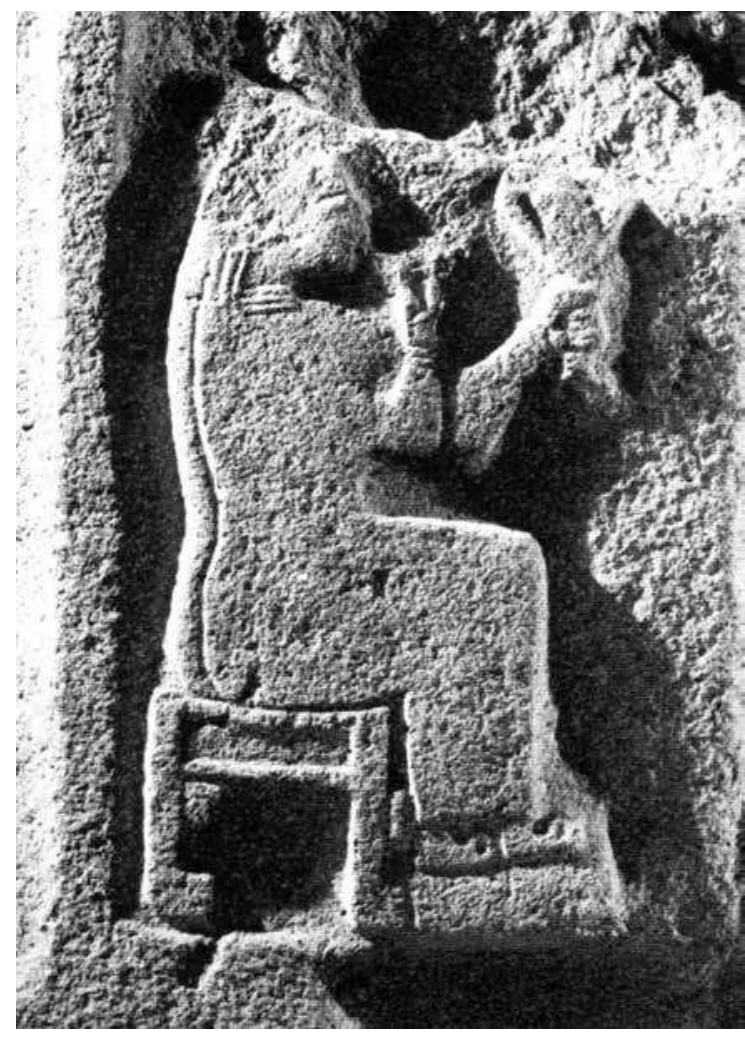

Fig. 5.13: Seated goddess. Relief from Alaca Höyük (14th century BC). Detail. Bittel 1976, fig. 216. them, the subject is complicated by the difficulty on how these hues were perceived. ${ }^{315}$

Apart from the Egyptian wall paintings and faïence tiles, the only support in Anatolian visual art comes from the Reliefkeramik, dating back to 16th century BC. ${ }^{316}$ The red-polished surface of these vases was decorated in relief with the additional use of some colours like dark brown and white/cream. ${ }^{317}$ In some cases the decoration involved human figures. These are men and women participating in a rite, some sort of a sacred marriage ceremony. Men wear short white/cream tunics with long sleeves, but in some cases we observe a sort of back extension that looks like a swallowtail (Fig. 5.16). ${ }^{318}$ More seldom we note men wearing long, long-sleeved tunics of dark brown colour (Fig. 5.14). Women are usually dressed in white or cream long tunics with long sleeves, but dark tunics are also attested (Figs 5.14-5.16). Both men and women wearing this kind of long tunics

\footnotetext{
312 This is the case of the queen as represented on a block relief in Alaca Höyük, here Fig. 5.7.

313 Ehringhaus 2005, 22-23, figs 32-33.

314 Bittel 1976, 253, fig. 287; 255, fig. 289.

315 See Vigo 2010, 298-302, with references and previous paragraph.

${ }^{316}$ For an overview see Özgüç 2002. On the Bitik vase, see Özgüç 1957; Bittel 1976, 145; on İnandık vase, see Özgüç 1988; on the recently discovered Hüseyindede vase, see Y1ldırım 2009.

317 These colours - reddish-brown, very dark brown and cream (sometimes going to yellow) - are the local traditional colours beginning with this very period. Cf. Bittel 1976, 145.

318 Bittel 1976, 145, fig. 144. Özgüç 1988, Pl. I; Yıldırım 2009, Pls. 27-29, figs 8-12.
} 


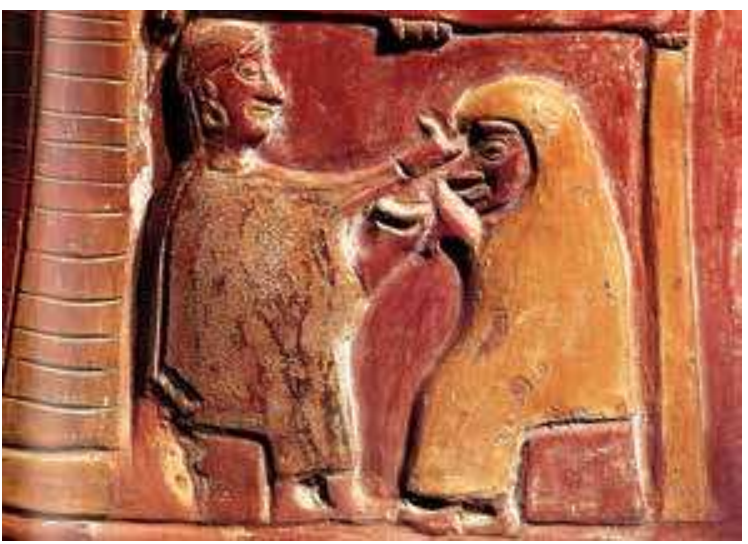

Fig. 5.14: Royal (?) couple involved in a ceremony. Fragment of the Bitik vase (16th century BC). Bittel 1976, fig. 140.

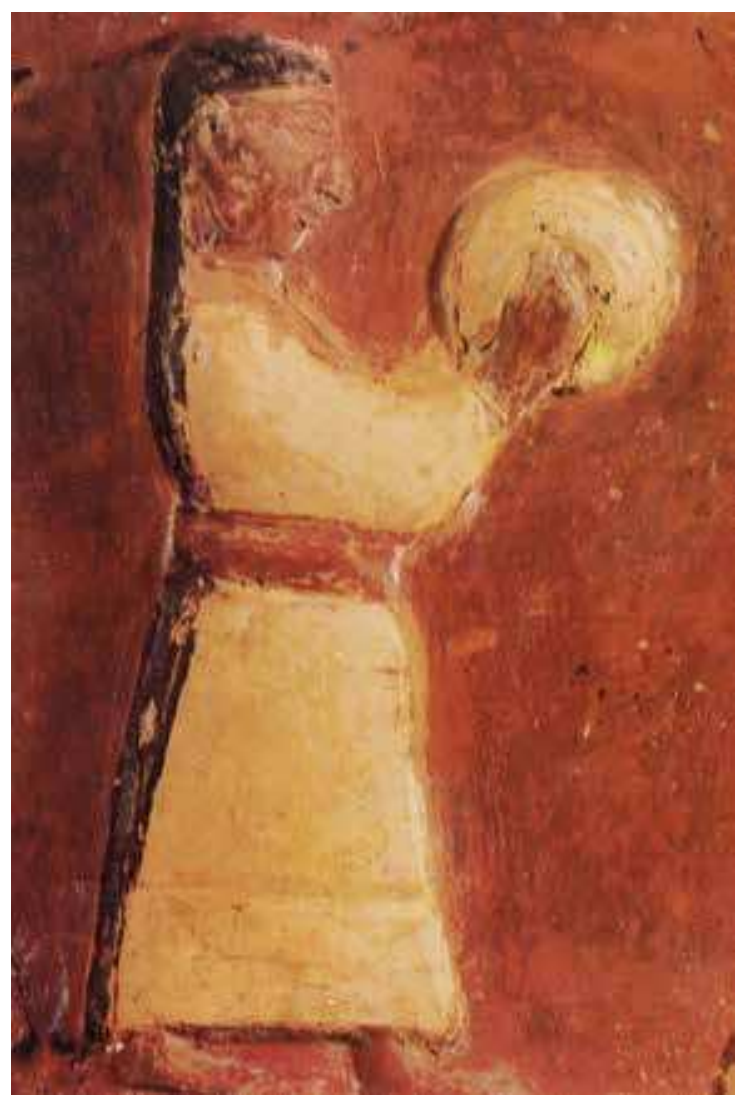

Fig. 5.15: Woman, musician. Detail of the frieze of the İnandlk vase (16th century BC). Özgüç T. 1988, Pl. K, fig. 3. also wear a thick reddish brown belt around their waists, although sometimes it is hidden as in the case of the couple involved in a sort of marriage scene on the Bitik vase (Fig. 5.14). ${ }^{319}$ Women are sometimes depicted with a long veil covering their heads and whole bodies; this is the case of the female figures sitting on the bed on İnandik vase and Hüseyndede vase and on the seat on the Bitik vase. In other cases the veil, coloured in dark brown, looks lighter and follows the back of the figures to the feet (Fig. 5.15). ${ }^{320}$

As already stressed, the garments worn by these figures are indicated in white (in some cases fading to yellow), with few exceptions. In some examples decorative bands are marked, coloured in dark brown or in relief. ${ }^{321}$

Men, women, gods and goddesses represented in Hittite art wear a peculiar kind of shoes with the point turned upwards. Identified as KuŠE. SIR ${ }^{\text {HI.A }}$ by scholars, they were usually made of leather and not included in the present paper.

Other uses for textiles among the Hittites are, unfortunately, rarely represented in art. The sample provided here deals with interior furnishings, such as beds.

Hittite inventory texts list precious textiles. Among other luxury goods, these catalogues of gifts or tributes register lakkušanzani-linen, interpreted as a kind of bed cover, ${ }^{322}$ or a sort of canopy for the bed. ${ }^{323}$ In Hittite art, one cannot yet find any representation of canopy beds. Although model beds are quoted in texts for ritual purposes, the actual models have not been preserved and this piece of furniture is not usually represented in art. ${ }^{324}$ The decoration of one of the friezes of the İnandık vase includes

319 Cf. Bittel 1976, 143, fig. 140.

320 Özgüç 1988, Pl. I, 4, Pl. K, 3.

321 Özgüç 1988, Pl. K, 4.

322 Siegelová 1986, 604.

323 Košak 1982, 17; recently Vigo 2010, 297.

${ }^{324}$ In Mesopotamia bed models or other representations of beds in art exist, for example in scenes of sexual intercourse or in scenes involving death or the healing of a sick person. See Nevling Porter 2002. 


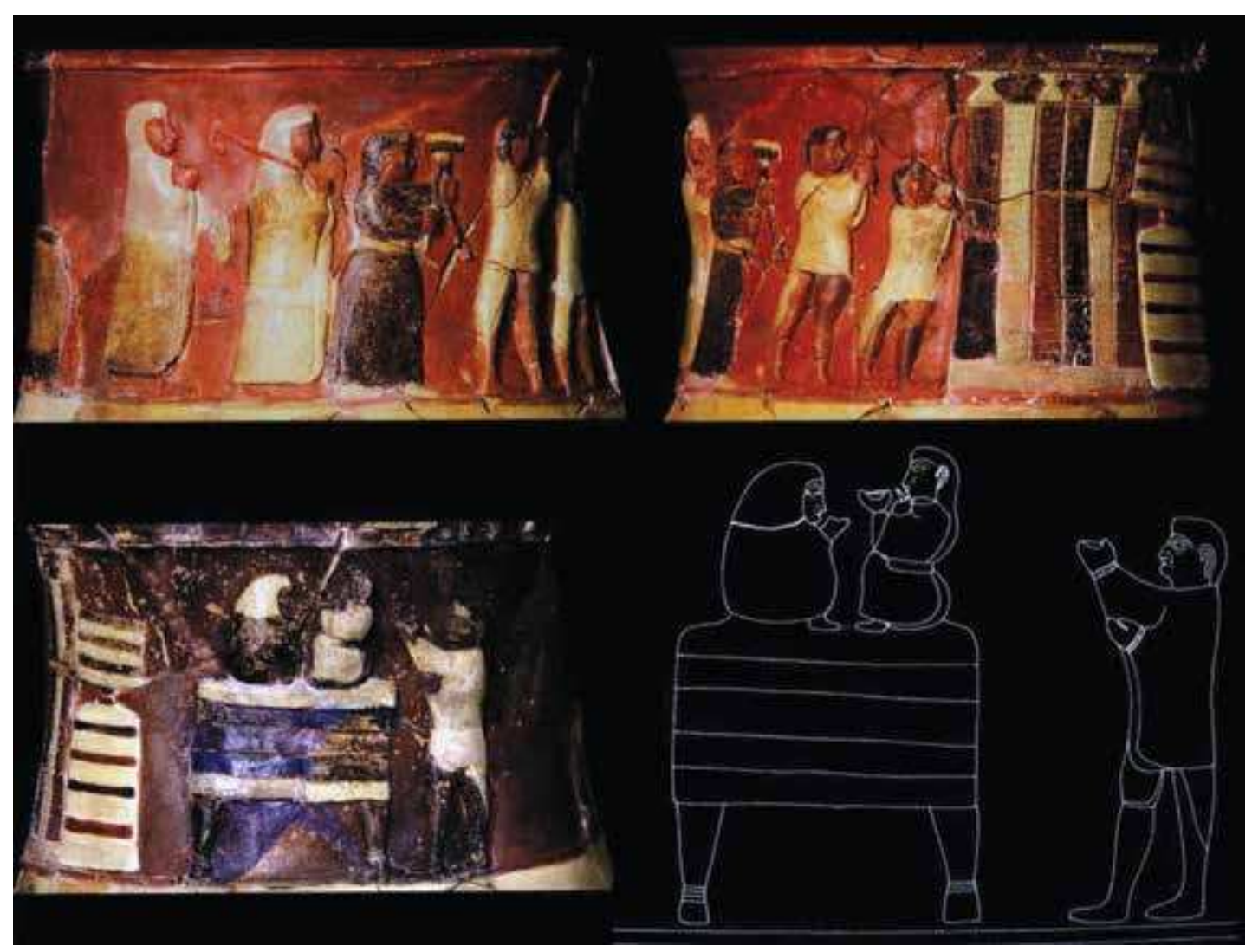

Fig. 5.16: Different scenes from the frieze of vase found in Hüseyndede (16th century BC). Ylldirtm 2009, Pl. 28, fig. 11 .

a rare image of a tall bed. ${ }^{325}$ Either rich sheets or blankets cover the bed leaving the legs exposed. It appears basically white, decorated with two horizontal bands, one black and one brownish-red (the uncoloured surface of the vase).

The recent publication of the Hüseyndede vase adds a second artistic example of the same kind of bed (Fig. 5.16). ${ }^{326}$ In this second example the bed is even higher, while the clothing is decorated with five bands: two white/cream and three very dark brown. The material of the sheets is unknown, although we cautiously opt for linen, considered more prestigious. ${ }^{327}$

Looking for comparisons in other representations from the ancient Near Eastern art, we encounter in Neo-Assyrian art some images of precious beds on which the king rests. Although these are not canopy beds, in some cases they were surmounted by precious tents that protected his majesty from the sun. Urartu art (1st millennium BC Eastern Anatolia), confirms the use of precious

\footnotetext{
325 Scholars have interpreted the relief of a couple sitting on this bed as a sacred marriage ceremony (Özgüç 1988, 96, Pl. 51.1.). This interpretation has to be re-discussed in the light of the new evidence from Hüseyndede.

326 Y1ldirim 2009, Pl. 28, fig. 11.

327 See the list of linen as bed clothes in Vigo 2010, 297 notes 68-69. On the prestigious use of linen attested in Mesopotamian texts see Waetzoldt apud Breniquet 2010, 54.
} 
embroidered textiles. A beautiful metal belt depicts a veiled queen walking and performing some kind of ritual. ${ }^{328}$ Two attendants protect her with a tasselled canopy. A second metal belt shows an almost identical procession, ${ }^{329}$ but in this case there is also a nuptial bed. Two women raise sheets over it and allow interpreting the scene as a kind of marriage ceremony similar to that represented on the Old Hittite vases.

Artistic objects from other periods and geographical areas inform us that many other textiles were gifted as luxury goods. Neo-Assyrian reliefs and Urartian belts provide many examples of beautiful carpets and tapestries. ${ }^{330}$ These objects were probably a work of art by themselves, as confirmed by the finding of a richly embroidered carpet in the so-called Pazyryk tomb (mid. 1st millennium BC). ${ }^{331}$ Unfortunately, archaeological excavations in Anatolian and surrounding areas only reveal traces of these textile items. ${ }^{332}$

\section{Concluding Remarks}

The main purpose of the general overview of production and use of textiles in the 2 nd millennium Anatolia presented here was to offer some elements for future comparative studies.

In doing so, we have tried to join the information provided by archaeological data, written documentation and iconography. The comparative approach of our research was successful in some cases, less so in others. As far as textile production of Hittite Anatolia is concerned, we have shown that weaving activities in domestic contexts are mostly drawn from the analysis of the archaeological data, but cannot be proved by written sources. On the contrary, the clay tablets found in the Hittite archives tell us something about the textile production in Anatolia, Syria and other neighbouring areas that did not leave archaeological traces. Pertaining to use, the presence of textile remains in funerary contexts of Hittite Anatolia can only be confirmed by Hittite funerary texts. Nevertheless, archaeology provides us with interesting finds from neighbouring areas and/ or different periods (3rd millennium BC). Moreover, the multidisciplinary approach (iconography and philology) demonstrates that is sometimes possible to define the garments worn by Hittite elites, those exchanged between Near Eastern courts and the ready-to-wear dresses. The analysis of texts cannot be exhaustive in defining the spinning or weaving techniques of that time, because the clay tablets we have discussed were not meant to instruct anyone. The techniques mentioned are only incidentally preserved because they were part of a ritual. ${ }^{333}$ The daily practices of these activities were carried out by skilled artisans and common people too (women in their domestic environments). In this context the related instructions were most likely transmitted orally. Perhaps the Hittite documentation offers examples of techniques that needed to be written, such as the glassmaking instructions and the horse training. This is surely not the case of the Hittite Textiltechnik. The evidence considered here brings to light the lack of representations of spinning and weaving in Hittite Anatolia. One finds textile tools simply represented in ancient Anatolian art. Yet, when

\footnotetext{
328 Ziffer 2002, 647 and fig. 4.

${ }^{329}$ Kellner 1991 No. 282.

${ }^{330}$ An example of a stone threshold from the Assyrian palace of Khorsabad imitating a carpet is A17598, Oriental Institute Museum, Chicago.

${ }^{331}$ For tapestries see Völling 2008, 173-181 and figures; now Smith 2013. For Assyrian textiles, Dalley 1991.

${ }^{332}$ See section 3.1 .

333 On the problem of the prescriptive $v s$. descriptive character of many "Hittite rituals"; the "Kizzuwatnean" ones in particular, see, above all, Miller 2004, 1-5; 476; 536-537.
} 
observing these images closer, one can automatically interpret them differently. Iconography evolves to iconology: attempting to talk of quotidian life and local economy, one is forced to consider symbolism and religion. This lack of information does not mean insufficiency of Hittite visual representations. Rather, it means the absence of representation of daily life among the Hittites. The few narrative scenes recognizable on Hittite reliefs, for example, the ones found in Alaca Höyük, deal with rituals or sacred hunting, not with everyday life. Reliefs never depict battle and military triumph scenes. Hittite art was highly representative and served to perpetuate the high standing of the king. By focusing on religious aspects, this art reveals the piety of the king and his exclusive connection with gods. For this reason, the lack of spinning and weaving representations is not surprising, despite the fact that the crafting of textiles indeed comprised a very important component in the Hittite world.

The comparison among iconographic sources, archaeological remains and texts for the crafting of textiles in Hittite Anatolia encounters many problems. Some of the challenges in analysing these data include a difference in the quantity and quality along with the large chronological span.

As stated above, the few representations of spinning tools date to Middle and Late Bronze Age and to Iron Age Anatolia. Regarding the Early Bronze Age, the data is mainly derived from archaeological finds, and for the Hittite period mainly from texts. But, even if one compares this data in some way to "even out" the chronological span, there is a difference in meaning. The aim of the visual representation of spindles and distaffs (both on seals and on stelae) was clearly not to depict actual spinning. The same happens with texts. As pointed out, the texts that mention terms for spindle and distaff are not economic or administrative but mainly describe rituals. The comparison between epigraphy and art history is in this case possible and interesting, but does not properly concern the production of yarns. Spinning is a metaphor. The analysis of archaeological finds of spinning tools in Anatolia is partly headed in the same direction. Metal spindles were found in the contexts of graves. It becomes possible to compare archaeological finds and iconography of spindles. But were these tools really used? They were probably ritual items, used in life or forged just for funerary deposits.

A huge amount of spindle whorls also come from all principal Anatolian sites. The items are made mainly of clay and testify the regular, "real", spinning practice.

Fabrics and garments are listed in texts, but usually not described. They were found in excavations both in funerary and non-funerary contexts, but in a very poor state of preservation. Fabrics and garments are represented in visual art and provide important information about forms and tradition. The only garments depicted in art include those of religious contexts, similar to those worn by deities. Were these real garments? The appearance of some of the luxury clothes in art and in texts confirms that these garments were real. They were produced in Anatolia or in the surrounding regions - maybe in northern Syria - sent as tributes or gifts to the Hittite capital, treasured or committed to be refined and then worn during rituals and representative moments. These are the garments sculpted on block or rock reliefs, entrusted to eternity.

Because this field of research is very intriguing and liable to future expansion, archaeologists, art historians and philologists need the support of specialists from different disciplines. Scholars should combine linguistic analysis on textile terminology with knowledge provided by experimental archaeology in order to decode the terms of a technique, foreign to us today, and define the solid know-how's of crafts. Moreover, experts in topography, together with natural scientists, could help the archaeologists to define "textile topography". 
Although the discrepancy between the North European tool-and-technique method and the South European historical method defines the framework of textile research around the world, research centres, such as the Danish National Research Foundation's Centre for Textile Research in Copenhagen, are developing projects that lead in this direction. ${ }^{334}$ We hope that in the near future there will be other opportunities to merge different proficiencies and academic disciplines in order to obtain a more detailed and comprehensive picture of ancient textiles in addition to the one sketched here for the Hittite Anatolia.

\section{Acknowledgements}

Giulia Baccelli wrote 2.1., 2.2., 3.1.; Benedetta Bellucci wrote 2.4., 3.3., 4. (together with M.V.); Matteo Vigo wrote 1., 1.1., 2.3., 3.2., 4. (together with B.B.). The authors wish to thank C. Michel and Th. P. J. van den Hout for their helpful comments.

\section{Abbreviations}

AAS

ARET

ARM

BASOR

Bo

$\mathrm{BoHa}$

CAD

CHD

CRAI

$\mathrm{CTH}$

$\mathrm{DBH}$

EA

EDHIL

HED

HEG

$\mathrm{HW}^{2}$
Annales archéologiques arabes syriennes. Damascus.

Archivi Reali di Ebla: Testi. Roma.

Archives Royales de Mari. Paris.

Bulletin of the American Schools of Oriental Research. Philadelphia - Boston. Inventory numbers of Boğazköy tablets excavated 1906-1912.

Boğazköy - Hattuša. Ergebnisse der Ausgrabungen. Berlin.

R. D. Biggs, J. A. Brinkman, M. Civil, W. Farber, I. J. Gelb", A. L. Oppenheim†, E. Reiner', M. T. Roth and M. W. Stolper (eds), The Assyrian Dictionary of the Oriental Institute of the University of Chicago. Chicago 1956-2011.

H. G. Güterbock ${ }^{\dagger}$, H. A. Hoffner Jr. and Th. P. J. van den Hout (eds), The Hittite Dictionary of the University of Chicago. Chicago 1980-.

Comptes Rendus des Séances de l'Académie des Inscriptions et Belles Lettres. Paris.

E. Laroche, Catalogue des Textes Hittites. Paris 1971.

Dresdner Beiträge zur Hethitologie. Wiesbaden.

Texts from el-Amarna, according to J. A. Knudtzon, Die el-Amarna-Tafeln, Vorderasiatische Bibliothek 20. Leipzig 1915.

A. Kloekhorst, Etymological Dictionary of the Hittite Inherited Lexicon, Leiden Indo-European Etymological Dictionary Series 5. Leiden - Boston 2008.

J. Puhvel, Hittite Etymological Dictionary. Berlin - New York - Amsterdam 1984-.

J. Tischler, Hethitisches Etymologische Glossar, Innsbrucker Beiträge zur Sprachwissenschaft-Band 20. Innsbruck 1983-.

J. Friedrich ${ }^{\dagger}$, A. Kammenhuber ${ }^{\dagger}$, (A. Hagenbuchner-Dresel et alii) (eds), Hethitisches Wörterbuch. (Zweite, völlig neubearbeitete Auflage auf der Grundlage der edierten hethitischen Texte). Heidelberg 1975-.

$\overline{334 \text { http://ctr.hum.ku.dk/ }}$ 
HZL

IBoT

JANER

JBL

JCS

JEOL

KBo

KUB

LSU

MDOG

MIO

MSL

MZL

NABU

NBC

OIP

PIHANS

RGTC VI

RGTC VI/2

R1A

StBoT

TC

VBoT
C. Rüster and E. Neu, Hethitisches Zeichenlexikon - Inventar und Interpretation der Keilschriftzeichen aus den Boğazköy-Texten, StBoT-Beiheft 2. Wiesbaden 1989. Istanbul Arkeoloji Müzelerinde Bulunan Boğazköy Tabletleri(nden Seçme Metinler) - Istanbul 1944, 1947, 1954 - Ankara 1988.

Journal of Ancient Near Eastern Religions. Leiden - Boston.

Journal of Biblical Literature. Atlanta.

Journal of Cuneiform Studies. Baltimore.

Jaarbericht "Ex Oriente Lux". Leiden.

Keilschrifttexte aus Boghazköi. Berlin 1916-.

Keilschrifturkunden aus Boghazköi. Berlin 1921-.

K. K. Riemschneider, Die hethitischen Landschenkungsurkunden, MIO 6 (1958), 321-381.

Mitteilungen der Deutsche Orient-Gesellschaft zu Berlin. Berlin.

Mitteilungen des Instituts für Orientforschung. Berlin.

B. Landsberger, Materialen zum Sumerischen Lexikon. Roma 1937-.

R. Borger, Mesopotamischen Zeichenlexikon, Alter Orient und Altes Testament 305. Münster 2003.

Nouvelles Assyriologiques Brèves et Utilitaires. Paris.

Nies Babylonian Collection - Yale University.

Oriental Institute Publications. Chicago.

Publications de 1'Institut historique-archéologique néerlandais de Stamboul. Leiden.

G. F. del Monte and J. Tischler, Die Orts- und Gewässernamen der hethitischen Texte. Beihefte zum Tübinger Atlas des Vorderen Orients - Reihe B Geisteswissenschaften Nr. 7. Wiesbaden 1978.

G. F. del Monte, Die Orts- und Gewässernamen der hethitischen Texte: Supplement. Beihefte zum Tübinger Atlas des Vorderen Orients - Reihe B Geisteswissenschaften Nr. 7/Supplement. Wiesbaden 1992.

Reallexikon der Assyriologie und Vorderasiatischen Archäologie, Berlin 1928-. Studien zu den Boğazköy-Texten. Wiesbaden.

Tablettes cappadociennes du Louvre. Paris.

Verstreute Boghazköi-Texte, Marburg a.d. Lahn.

\section{Bibliography}

Al-Maqdissi M., Dohmann-Pfälzner, H., Pfälzner, P. and Suleiman, A. 2003 Das königliche Hypogäum von Qatna. Bericht über die syrisch-deutsche Ausgrabung im November-December 2002. MDOG 135, 189-218.

Alp, S. 1968 Zylinder- und Stempelsiegel aus Karahöyük bei Konya. Ankara.

Amiet, P. 1972 Glyptique Susienne, des origines à l'époque des Perses Achéménides. Paris.

Andersson, E., Felluca, E., Nosch, M.-L. and Peyronel, L. 2010 New Perspectives on Bronze Age Textile Production in the Eastern Mediterranean. The First Results with Ebla as a Pilot Study. In P. Matthiae, F. Pinnock, L. Nigro and N. Marchetti (eds), Proceedings of the 6th International Congress on the Archaeology of the Ancient Near East, Volume 2, 159-176. Wiesbaden.

Archi, A. 1975 Città Sacre d'Asia Minore. Il problema dei laoi e l'antefatto ittita. Parola del Passato 164, 329-344. Archi, A. 1985 Testi amministrativi: assegnazione di tessuti (Archivio L. 2769), ARET 1. Roma. 
Baccelli, G. (2011) Das Prestige und die Bedeutung von Textilien in West-Syrien in der II Jahr. Vor. Chr. Unpublished $\mathrm{PhD}$ thesis, Karls-Eberhards Universität Tübingen.

Balfanz, K. 1995 Eine spätbronzezeitliche Elfenbeinspindel aus Troja, VII A. Studia Troica 5, 107-116.

Barber, E. J. 1991 Prehistoric Textiles: The development of the Cloth in the Neolithic and Bronze Ages with special reference to the Aegean. Princeton.

Barber, E. J. 1994 Women's Work. The First 20.000 Years. Women, Cloth, and Society in Early Times. New York/London. Beckman, G. 1983 Hittite Birth Rituals - Second Revised Edition, StBoT 29. Wiesbaden.

Beckman, G. 1996 Hittite Diplomatic Texts, Society of Biblical Literature: Writings from the Ancient World 7. Atlanta. Bellinger, L. 1962 Textiles from Gordion. Bullettin of the Needle and Bobbin Club 46, 4-33.

Beyer, D. 2001 Emar IV-Les sceaux, Orbis Biblicus et Orientalis - Series Archaeologica 20. Fribourg (Switzerland)/ Göttingen.

Bier, C. 1995 Textile Arts in Ancient Western Asia. In J. Sasson (ed.), Civilizations of the Ancient Near East, 1567-1588. New York.

Biga, M. G. 1992 Les vêtements neufs de l'Empereur. NABU 19, 16-17.

Biga, M. G. 2010 Textiles in the Administrative Texts of the Royal Archives of Ebla (Syria 24th Century BC) with Particular Emphasis on Coloured Textiles. In C. Michel and M.-L. Nosch (eds), Textile Terminologies in the Ancient Near East and the Mediterranean Area from the 3rd to the 1st millennium BC, Ancient Textiles Series 8, 146-185. Oxford.

Biga, M. G. and Milano, L. 1984 Testi amministrativi: assegnazioni di tessili (Archivio L.2769), ARET 4. Roma.

Bittel, K. 1975 Das hethitische Felsheiligtum Yazılıkaya. Berlin.

Bittel, K. 1976 Les Hittites. Paris.

Blegen, C. W. 1963 Troy and Trojans. New York.

Blegen, C. W., Caskey, J. L., Rawson, M. and Sperling, J. 1950 Troy, Vol. I. General Introduction: The First and Second Settlements. Princeton.

Boehmer, R. M. and Güterbock, H. G. 1987 Glyptik aus dem Stadtgebiet von Boğazköy, BoHูa 14. Berlin.

Bonatz, D. 2000a Das syro-hethitische Grabdenkmal. Mainz.

Bonatz, D. 2000b Syro-hittite Funerary Monuments. A Phenomenon of Tradition or Innovation? In G. Bunnens (ed.), Essays on Syria in the Iron Age, Ancient Near Eastern Studies Supplement 7, 189-210. Louvain-ParisSterling, Virginia.

Bonatz, D. 2007 The Divine Image of the King: Religious Representation of Political Power in the Hittite Empire. In M. Heinz and M. H. Feldman (eds), Representation of Political Power. Case Histories from Times of Change and Dissolving Order in the Ancient Near East, 111-136. Winona Lake.

Bordaz, L. A. 1980 The Metal Artefacts from the Bronze Age. Excavations at Karataş.-Semayük. Turkey and their Significance in Anatolia, the Near East and the Aegean. London.

Breniquet, C. 2008 Essai sur le tissage en Mésopotamie: des premières communautés sédentaires au milieu du 3e millénaire avant J.-C. Paris.

Breniquet, C. 2010 Weaving in Mesopotamia during the Bronze Age: Archaeology, techniques, iconography. In C. Michel and M.-L. Nosch (eds), Textile Terminologies in the Ancient Near East and the Mediterranean Area from the 3rd to the 1st millennium BC, Ancient Textiles Series 8, 52-67. Oxford.

Burke, B. 2005 Textile Production at Gordion and the Phrygian Economy. In E. Kealhofer (ed.), The Archaeology of Midas and the Phrygians: Recent Work at Gordion, 69-81. Philadelphia.

Burke, B. 2010 From Minos to Midas. Ancient Cloth Production in the Aegean and in Anatolia, Ancient Textiles Series 7. Oxford.

Burnham, H. B. 1965 Çatal Höyük. The Textiles and the Twined Fabrics. Anatolian Studies 15, 169-174.

Calmayer, P. 1995 Möbel. B. Archäologisch. RlA 8, 334-337.

Christiansen, B. 2006 Die Ritualtradition der Ambazzi. Eine philologische Bearbeitung und entstehungsgeschichtliche Analyse der Ritualtexte CTH 391, CTH 429, und CTH 463, StBoT 48. Wiesbaden.

Cottica, D. and Rova, E. 2006 Fuso e rocca: un percorso fra Occidente e Oriente alla ricerca delle origini di una simbologia. In D. Morandi Bonacossi, E. Rova, F. Veronese and P. Zanovello (eds), Tra Oriente e Occidente. Studi in onore di Elena Di Filippo Balestrazzi, 291-322. Padova.

Crowfoot, J. W. 1899 Exploration in Galatia Cis Halym, The Journal of Hellenic Studies 19, 34-318. 
Crowfoot, E. 1960 Report on Textiles. In K. Kenyon (ed.), Excavations at Jericho 1, 519-526. London.

Crowfoot, E. 1965 Report on Textiles. In K. Kenyon (ed.), Excavations at Jericho 2, 662-663. London.

D'Alfonso, L. 2010 'Servant of the king, son of Ugarit, and servant of the servant of the king': RS 17.238 and the Hittites. In Y. Cohen, A. Gilan and J. L. Miller (eds), Pax Hethitica - Studies on the Hittites and their Neighbours in Honour of Itamar Singer, StBoT 51, 67-86. Wiesbaden.

Dalley, S. 1991 Ancient Assyrian Textiles and Origins of Carpet Designs. Iran 29, 117-132.

Darga, A. M. 1992, Hitit Sanat. Istanbul.

Desroiers, S. 2010 Textile Terminologies and Classifications: Some Methodological and Chronological Aspects. In C. Michel and M.-L. Nosch (eds), Textile Terminologies in the Ancient Near East and the Mediterranean Area from the 3rd to the 1st millennium BC, Ancient Textiles Series 8, 23-51. Oxford.

Dohmann-Pfälzner H. and Pfälzner P. 2011 Archäologischer Kontext und Rekonstruktion des Bestattungstisches in Kammer 4. In P. Pfälzner (ed.), Interdisziplinäre Untersuchungen zur Königsgruft in Qața, Qațna Studien 1, 483-485. Wiesbaden.

Ehringhaus, H. 2005 Götter, Herrscher, Inschriften. Die Felsreliefs der hethitischen Grossreichszeit in der Türkei. Mainz am Rhein.

Elliot, C. 1991 The Ground Stone Industry. In M. Yon (ed.), Ras Shamra-Ougarit 6. Arts et industries de la pierre, 9-99. Paris.

El-Shahawy, A. 2005 The Egyptian Museum in Cairo: a walk through the alleys of ancient Egypt. Cairo.

Emre, K. 1978 Yanarlar. Afyon yöresinde bir hitit mezarligi- A Hittite Cemetery near Afyon. Ankara.

Fairbairn, A. 2004 Archaeobotany at Kaman-Kalehöyük 2003. Kaman-Kalehöyük Anatolian Archaeological Studies 13, 107-120.

Farber, W. 1980-1983 Lamaštu. RlA 6, 439-446.

Fogelberg, J. M. and Kendall, A. I. 1937 Chalcolithic Textile Fragments. In H. H. von der Osten, J. A. Wilson and Th. G. Allen (eds), The Alishar Höyük 1930-1932 III, OIP 30, 334-335. Chicago.

Foster, B. R. 2010 Clothing in Sargonic Mesopotamia: Visual and written evidence. In C. Michel and M.-L. Nosch (eds), Textile Terminologies in the Ancient Near East and the Mediterranean Area from the 3rd to the 1st millennium BC, Ancient Textiles Series 8, 110-145. Oxford.

Frangipane, M., Andersson, E., Laurito, R., Möller-Wiering, S., Nosch, M.-L., Rast-Eicher, A. and Wisti Lassen A. 2009 Arslantepe (Turkey): Textiles, Tools and Imprints of Fabrics from the 4th to the 2nd millennium BC. Paléorient 35/1, 5-30.

Garstang, J. 1929 The Hittite Empire. Being a Survey of the History and Monuments of Hittite Asia Minor and Syria. London.

Gachet-Bizollon, J. 2007 Ras Shamra-Ougarit 16. Les Ivoires d'Ougarit. Paris.

Gelb, I. J. 1955 Old Akkadian Inscriptions in Chicago Natural History Museum. Texts of Legal and Business Interest. Chicago.

Goetze, A. 1947a The Priestly Dress of the Hittite King. JCS 1, 176-185.

Goetze, A. 1947b Contributions to Hittite Lexicography. JCS 1, 307-320.

Goetze, A. 1955 Hittite dress. In H. Krahe (ed.), Corolla Linguistica. Festschrift Ferdinand Sommer zum 80. Geburtstag am 4. Mai 1955, 48-62. Wiesbaden.

Goetze, A. 1956 The Inventory IBoT I 31. JCS 10, 32-38.

Goldman, H. 1956 Excavations at Gözlu Kule, Tarsus II. Princeton.

Groddek, D. 1999 Fragmenta Hethitica dispersa VII/VIII. Altorientalische Forschungen 26/1, 33-52.

Groddek, D. 2005 Hethitische Texte in Transkription. KUB 58, DBH 18. Wiesbaden.

Groddek, D. 2007 Varia Mythologica. In D. Groddek and M. Zorman (eds), Tabularia Hethaeorum. Hethitologische Beiträge Silvin Košak zum 65. Geburtstag, DBH 25, 331-339, Wiesbaden.

Guy, P. L. O. 1938 Megiddo Tombs, OIP 33. Chicago.

Haas, V. 1994 Geschichte der hethitischen Religion, Handbuch der Orientalistik I/15. Leiden.

Haas, V. 2003 Materia Magica et Medica Hethitica - Ein Beitrag zur Heilkunde im Alten Orient Vol. II. Berlin/ New York.

Hazenbos, J. 2003 The Organization of the Anatolian Local Cults during the Thirteenth Century B.C. An Appraisal of the Hittite Cult Inventories, Cuneiform Monographs 21. Leiden/Boston. 
Herbordt, S. 2005 Die Prinzen- und Beamtensiegel der hethitischen Grossreichszeit auf Tonbullen aus dem Nişantepe-Archiv in Hattusa, BoHुa 19. Mainz.

Herbordt, S. et al. 2011, Die Siegel der Grosskönige und Grossköniginnen auf Tonbullen aus dem Nişantepe Archiv in Hattusa, BoHa 23. Mainz.

Hoffner, H. A. Jr. 1966 Symbols for Masculinity and Femininity. Their Use in Ancient Near Eastern Sympathetic Magic Rituals. JBL 85, 326-334.

Hoffner, H. A. Jr. 1997 The Laws of the Hittites. A Critical Edition. Leiden/New York/Köln.

Hoffner, H. A. Jr. and Melchert, H. C. 2008 A Grammar of the Hittite Language. Winona Lake.

van den Hout, Th. P. J. 1995 Tuthalija IV, und die Ikonographie hethitischer Großkönige des 13. Jhs., Bibliotheca Orientalis 52/5-6, 546-571.

van den Hout, Th. P. J. 2010, LÚDUB.SAR.GIŠ - "Clerk"? Orientalia 79, 255-267.

Houwink ten Cate, P. H. J. 1988 Brief Comments on the Hittite Cult Calendar: The Main Recension of the Outline of the nuntarriyašhaš Festival, especially Days 8-12 and 15-22. In E. Neu, and Ch. Rüster, (eds), Documentum Asiae Minoris Antiquae. Festschrift für Heinrich Otten zum 75. Geburtstag, 167-194. Wiesbaden.

James, M. A., Reifarth, N., Mukherjee, A. J., Crump, M. P., Gates, P. J., Sandor, P., Robertson, F., Pfälzner, P. and Evershed, R. P. 2009 High prestige Royal Purple dyed textiles from the Bronze Age royal tomb at Qatna, Syria. Antiquity 83 (322), 1109-1118.

James M., Reifarth, N. and Eversched, R. P. 2011 Chemical Identification of Ancient Dyestuffs from Mineralised Textile Fragments from the Royal Tomb. In P. Pfälzner (ed.), Interdisziplinäre Untersuchungen zur Königsgruft in Qața, Qațna Studien 1, 449-468. Wiesbaden.

Kassian, A., Korolev, A. and Sidel'tsev, A. 2002 Hittite Funerary Rituals. šalliš waštaiš, Alter Orient und Altes Testament 288. Münster.

Kellner, H. J. 1991 Gürtelbleche aus Urartu. Stuttgart.

Kemp, B. J. and Vogelsang-Eastwood, G. 2001 The Ancient Textile Industry at Amarna. Egyptian Exploration Society. London.

Klengel, H. 2008 Studien zur hethitischen Wirtschaft 4. Das Handwerk. Werkstoffe: Wolle und Leder, Holz und Rohr. Altorientalische Forschungen 35/1, 68-85.

Klengel, H. and Klengel, E. 2009 "Hurritische Hemden" in den keilschriftlichen Tradition. Altorientalische Forschungen 36/2, 205-208.

Klinger, J. 1992 Fremde und Außenseiter in Hatti. In V. Haas (ed.), Außenseiter und Randgruppen. Beitrage zu einer Sozialgeschichte des Alten Orients. Xenia 32, 187-212.

Košak, S. 1982 Hittite Inventory Texts (CTH 241-250), Texte der Hethiter 10. Heidelberg.

Košak S. 2002 http://www.hethport.uni-wuerzburg.de/hetkonk/.

Košay, H. 1951 Les Fouilles d'Alacahöyük, Rapport préliminaire sur les travaux en 1937-39. Ankara.

Košay, H. and Akok, M. 1966 Ausgrabungen von Alaca Höyük. Vorbericht über die Forschungen und Entdeckungen von 1940-1948. Ankara.

Kull, B. 1988 Textilherstellung (Spinnen und Weben) Textilgerät. In M. Korfmann (ed.), Demircihüyük V, Die Mittelbronzezeitliche Siedlung, 196-205. Mainz.

Lebrun, R. 1976 Samuha, foyer religieux de l'empire hittite, Louvain la-Neuve.

Leemans, W. F. 1960 Legal and Administrative Documents of the Time of Hammurabi and Samsuiluna (Mainly from Lagaba), Studia ad Tabulas Cuneiformes a F. M. Th. De Liagre Böhl Collectas Pertinentia: 1/3. Leiden.

Lloyd, S. and Mellaart, J. 1965 Beycesultan II. London.

van Loon, M. N. 1978 Korucutepe 2. Amsterdam/New York/Oxford.

Loud, G. 1939 The Megiddo Ivories. Chicago.

Macqueen, J. G. 1975 The Hittites and their Contemporaries in Asia Minor. London.

Mallet, J. 1987 Le temple aux rhytons. In M. Yon (ed.) Ras Shamra-Ougarit 3. Le Centre de la Ville, 38e-44e campagnes (1978-1984), 213-248. Paris.

Marazzi, M. 1982 “Costruiamo la reggia, 'fondiamo' la regalità”: Note intorno ad un rituale antico-ittita (CTH 414). Vicino Oriente 5, 117-169.

Matthiae, P., Pinnock, F. and Scandone-Matthiae, G. 1995 Ebla. Alle origini della civiltà urbana. Trent'anni di scavi in Siria dell'Università di Roma "La Sapienza". Roma. 
Matthiae, P. 1998 Les fortifications de l'Ebla paléo-syrienne: Fouilles à Tell Mardikh, 1995-1997. CRAI 1998, 555-586.

Mazzoni, S. 2002 The squatting woman: Between Fertility and Eroticism. In S. Parpola and R. M. Whiting (eds), Sex and Gender in the Ancient Near East. Proceedings of the 47th Rencontre Assyriologique Internationale, Helsinki, July 2-6, 2001, 367-377. Helsinki.

Melchert, H. C. 1998 Once more Greek $\tau 0 \lambda u ́ \pi \eta$, Orpheus-JIEThS 8, (2000= Memorial Volume of V.I. Georgiev), 47-51. Melchert, H. C. 1999 Hittite karzan- 'basket of wool'. In S. de Martino and F. Imparati (eds), Studi e Testi II, Eothen 10, 121-132. Firenze.

Melchert, H. C. 2001 A Hittite fertility rite? In G. Wilhelm (ed.), Akten des IV. Internationalen Kongresses für Hethitologie. Würzburg, 4.-8. Oktober 1999, StBoT 45, 404-409. Wiesbaden.

Melchert, H. C. 2003 Hittite antaka- "loins" and an Overlooked Myth about Fire. In G. M. Beckman and R. H. Beal and G. McMahon (eds), Hittite Studies in Honor of Harry A. Hoffner Jr. on the Occasion of His 65th Birthday, 281-287, Winona Lake.

Melchert, H. C. 2012 Hittite "Heteroclite" s-Stems, in ed. A. Cooper, J. Rau and M. Weiss (eds), Multi Nominis Grammaticus. Studies in Classical and Indo-European linguistics in honor of Alan. J. Nussbaum on the occasion of his sixty-fifth birthday, 175-184, Ann Arbor.

Mellaart, J. 1962 Excavation at Çatal Höyük. Anatolian Studies 12, 41-56.

Mellaart, J. and Murray, A. 1995 Beycesultan. Vol. III. Part II. Late Bronze Age and Phrygian Pottery and Middle and Late Bronze Age Small Objects. Ankara.

Mellink, M. 1956 A Hittite Cemetery at Gordion. Philadelphia.

Meriggi, P. 1975 Manuale di Eteo-geroglifico. Parte II: Testi $2^{a}$ e $3^{a}$ Serie. Roma.

Michel, C. 2001 Correspondance des marchands de Kaneš au début du II millénaire avant J.-C., Littérature anciennes du Proche-Orient 19. Paris.

Michel, C. and Nosch, M.-L. 2010a Textile Terminologies in the Ancient Near East and the Mediterranean Area from the $3 r d$ to the 1st millennium BC, Ancient Textiles Series 8. Oxford.

Michel, C. and Nosch, M.-L. 2010b Textile terminologies. In C. Michel and M.-L. Nosch (eds), Textile Terminologies in the Ancient Near East and the Mediterranean Area from the 3rd to the 1st millennium BC, Ancient Textiles Series 8, vii-xviii. Oxford.

Michel, C. and Veenhof, K. R. 2010 The Textiles Traded by the Assyrians in Anatolia (19th-18th Centuries BC). In C. Michel and M.-L. Nosch (eds), Textile Terminologies in the Ancient Near East and the Mediterranean Area from the 3rd to the 1st millennium BC, Ancient Textiles Series 8, 209-269. Oxford.

van de Mieroop, M. 1987 Crafts in the Early Isin Period. A Study of the Isin Craft Archive from the Reigns of Ishbi-Erra and Sh-Ilishu, Orientalia Lovaniensia Analecta 24. Leuven.

Miller, J. L. 2002 The katra/i-women in the Kizzuwatnean Rituals from Hattuša. In S. Parpola and R. M. Whiting (eds), Sex and Gender in the Ancient Near East Part II. Proceedings of the XLVII Rencontre Assyriologique Internationale, Helsinki, July 2-6, 2001, 423-431. Helsinki.

Miller, J. L. 2004 Studies in the Origins, Development and Interpretation of the Kizzuwatna Rituals, StBoT 46. Wiesbaden.

Miller, J. L. 2010 Paskuwatti Ritual: Remedy for Impotence or Antidote to Homosexuality? JANER 10/1, 83-89.

Mora, C. 2004 Sigilli e sigillature di Karkemiš in età imperiale ittita. I. I re, i dignitari, il (mio) Sole”. Orientalia 73, 427-450.

Mora, C. 2006 Riscossione dei tributi e accumulo dei beni nell'Impero ittita. In M. Marazzi and M. Perna (eds), Atti del Convegno «Fiscality in Mycenaean and Near Eastern Archives», Naples, 21-23 October 2004, 133-146. Napoli.

Mora, C. 2007 I testi ittiti di inventario e gli ‘archivi' di cretule. Alcune osservazioni e riflessioni. In D. Groddek and M. Zorman (eds), Tabularia Hethaeorum. Hethitologische Beiträge Silvin Košak zum 65. Geburtstag, DBH 25, 535-550.

Mora, C. and Vigo, M. 2012 Attività femminili a Huattuša. La testimonianza dei testi d'inventario e degli archivi di cretulae. In N. Bolatti-Guzzo, S. Festuccia and M. Marazzi (eds), Centro Mediterraneo Preclassico. Studi e Ricerche III. Studi vari di egeistica, anatolistica e del mondo mediterraneo, Serie Beni Culturali 20, 173-223. Napoli.

Nakamura, M. 2002 Das hethitische nuntarriyašhaš-Fest, PIHANS 94.

Neve, P. 1993 Hattuša. Stadt der Götter und Tempel. Mainz am Rhein. 
Nevling Porter, B. 2002 Beds, Sex, and Politics: The Return of Marduk's Bed to Babylon. In S. Parpola and R. M. Whiting (eds), Sex and Gender in the Ancient Near East. Proceedings of the 47th Rencontre Assyriologique Internationale, Helsinki, July 2-6, 2001, 523-535. Helsinki.

Oettinger, N. 1967 Die Militärische Eide der Hethiter, StBoT 22.

Ofitsch, M. $2001 \mathrm{Zu}$ heth. hueša-: Semantik, Etymologie, kulturgeschichtliche Aspekte. In G. Wilhelm (ed.), Akten des IV. Internationalen Kongresses für Hethitologie. Würzburg, 4.-8. Oktober 1999, StBoT 45, 478-498.

Orthmann, W. 1971 Untersuchungen zur späthethitischen Kunst, Saarbrücker Beiträge zur Altertumskunde 8. Bonn.

von der Osten, H. H. 1937 The Alishar Höyük, Seasons of 1930-32, Vol. I-III, OIP 28-30. Chicago.

Otten, H. 1988 Die Bronzetafel aus Boğazköy. Ein Staatsvertrag Tuthalijas IV., StBoT-Beiheft 1.

Otto, A. 2000 Die Entstehung und Entwicklung der Klassisch-Syrischen Glyptik. Berlin/New York.

Özgen, İ. 1985 A Study of Anatolian and East Greek Costume in the Iron Age. University Microfilm International.

Ann Arbor, Michigan.

Özgüç, N. and Tunca, Ö. 2001 Kültepe-Kaneš. Mühürlü ve yazttl kil bullalar. Sealed and Inscribed Clay Bullae. Ankara.

Özgüç, T. 1957 The Bitik Vase. Anatolia 2, 57-78.

Özgüç, T. 1982 Maşat Höyük II. A Hittite Center Northeast of Boghazköy. Ankara.

Özgüç, T. 1988 Inandiktepe. An Important Cult Center in the Old Hittite Period. Ankara.

Özgüç, T. 2002 Die Keramik der althethitischen Zeit. In AA.VV., Die Hethiter und ihr Reich. Das Volk der 1000 Götter, 248-255. Stuttgart.

Özgüç, T. and Akok, M. 1958 Horoztepe - An Early Bronze Age Settlement and Cemetery. Ankara.

Parrot, A. 1961-1962 La Douzième Campagne de Fouilles à Mari. AAS 11-12, 173-184.

Pasquali, J. 2005 Remarques comparatives sur la symbolique du vêtement à Ebla. In L. Kogan, N. Koslova, S. Loesov and S. Tishchenko (eds), Memoriae Igor M. Diakonoff, Babel und Bibel 2, 165-184. Winona Lake.

Pecchioli Daddi, F. 1982 Mestieri, professioni e dignità nell'Anatolia ittita, Incunabula Graeca 79. Roma.

Peyronel, L. 2004 Gli strumenti di tessitura. Dall'età del Bronzo all'epoca persiana, Materiali e Studi archeologici di Ebla-IV, Roma.

Pomponio, F. 2008 Testi amministrativi: assegnazioni mensili di tessuti. Periodo di Arrugum, ARET 15/1.

Pomponio, F. 2010 New Texts Regarding the Neo-Sumerian Textiles. In C. Michel and M.-L. Nosch (eds), Textile Terminologies in the Ancient Near East and the Mediterranean Area from the 3rd to the 1st millennium BC, Ancient Textiles Series 8, 186-200. Oxford.

Pritchard, J. B. 1951 Syrians as Pictured in the Paintings of the Theban Tombs. BASOR 122, 36-41.

Pritchard, J. B. 1969 The Ancient Near East in Pictures Relating to the Old Testament. (Second Edition with Supplement). Princeton.

Pritchard, J. B. 1980 The Cemetery at Tell el Sa'idìyeh, Jordan. Philadelphia.

Pruss, A. 2002 The Use of Nude Female Figurines. In S. Parpola and R. M. Whiting (eds), Sex and Gender in the Ancient Near East. Proceedings of the 47th Rencontre Assyriologique Internationale, Helsinki, July 2-6, 2001, 537-545. Helsinki.

Reifarth, N. 2011 Die Textilien vom Bestattungstisch in Kammer 4. Vorbericht zu den mikrostratigraphischen und textiltechnologischen Untersuchungen. In P. Pfälzner (ed.), Interdisziplinäre Untersuchungen zur Königsgruft in Qața, Qaṭa Studien 1, 499-526. Wiesbaden.

Reifarth, N. and Baccelli, G. 2009 Königsornat in Purpur und Gold- Die Textilfunde. In AA.VV, Schätzte des Alten Syrien, Die Endeckung des Königsreichs Qatna, 216-219. Stuttgart.

Reifarth, N. and Drewello, R. 2011 Textile Spuren in der Königsgruft. Vorbericht zu ersten Ergebnissen und dem Potential zukünftiger Forschungen. In P. Pfälzner (ed.), Interdisziplinäre Untersuchungen zur Königsgruft in Qața, Qațna Studien 1, 469-482. Wiesbaden.

Riemschneider, K. K. 1958 Die hethitischen Landschenkungsurkunden. MIO 6, 321-381.

Riis, P. J. 1948 Hama. Fouilles et recherches de la Fondation Carlsberg 1931-1938, II 3. Les cimetières à crémation. Copenhagen.

Róheim, G. 1948 The Thread of Life. Psychoanalytic Quarterly 17, 471-486.

Rouault, O. 1977a Mukannišum. L'administration et l'économie palatiales à Mari, ARM 18. 
Rouault, O. 1977b L'approvisionnement et la circulation de la laine à Mari. D'après une nouvelle lettre du roi à Mukannišum. Iraq 39, 147-153.

Rova, E. 2008 Mirror, Distaff, Pomegranate, and Poppy Capsule: on the Ambiguity of some Attributes of Women and Goddesses. In H. Kühne, R. M. Czichon and F. J. Kreppner (eds), Proceedings of the 4th International Congress of the Archaeology of the Ancient Near East. 29 March-3 April 2004, Frei Universität Berlin. Vol. I, 557-570. Berlin.

Rüster, Ch. and Wilhelm, G. 2012 Landschenkungsurkunden hethitischer Könige, StBoT-Beiheft 4.

Sallaberger, W. 2009 Von der Wollration zum Ehrenkleid. Textilen als Prestigegüter am Hof von Ebla. In B. Hildebrandt and C. Velt (eds), Der Wert der Dinge-Güter im Prestigediskurs, Münchner Studien zur Alten Welt 6, 241-278. München.

Sauvage, C. 2013 Spinning from old Threads: The Whorls from Ugarit at the Músee d'Archéologie Nationale (Saint-Germain-en-Laye) and at the Louvre. In M.-L. Nosch, H. Koefoed and E. Andersson-Strand (eds), Textile Production and Consumption in the Ancient Near East: Archaeology, Iconography, Epigraphy, Ancient Textiles Series 12, 189-214. Oxford.

Schaeffer, C. F. A. 1952 Enkomi-Alasia. Nouvelles missions en Chypre 1946-1950. Paris.

Shamir, O. 1996 Loom weights and Whorls. In D. T. Ariel and A. de Groot (eds), Excavations at the City of David, 1978-1985 IV. Qedem 35, 135-170.

Sharp Joukowsky, M. 1996 Early Turkey. Anatolian Archaeology from Prehistory through the Lydian Period. Dubuque, Iowa.

Siegelová, J. 1984 Gewinnung und Verarbeitung von Eisen im Hethitischen Reich im 2. Jahrtausend v.u.Z. Annals Náprstek Museum 12, 71-168.

Siegelová, J. 1986 Hethitische Verwaltungspraxis im Lichte der Wirtschafts- und Inventardokumente. Praha.

Siegelová, J. 1995 Möbel. A. II. Bei den Hethitern. RlA 8, 330-334.

Simon, Z. 2012 Hethitische Felsreliefs als Repräsentation der Macht - einige ikonographische Bemerkungen. In G. Wilhelm (ed.), Organization, Representation, and Symbols of Power in the Ancient Near East, Proceedings of the 54th Rencontre Assyriologique Internationale at Würzburg 20-25 July 2008, 699-714. Winona Lake.

Singer, I. 1984 The AGRIG in Hittite Texts. Anatolian Studies 34, 97-127.

Singer, I. 2002 Hittite Prayers. Atlanta.

Singer, I. 2007 Who were the Kaška?. Phasis 10, 166-178.

Singer, I 2008 Purple dyers in Lazpa. In B. J. Collins, M. R. Bachvarova and I. C. Rutherford (eds), Anatolian Interfaces. Hittite, Greeks and their Neighbours. Proceedings of an International Conference on Cross-Cultural Interaction, September 17-19, 2004 Emory University, Atlanta, GA, 21-43. Oakville.

Smith, J. S. 2013 Tapestries in the Bronze and Early Iron Ages of the Anceint Near East. In M.-L. Nosch, H. Koefoed and E. Andersson-Strand (eds), Textile Production and Consumption in the Ancient Near East: Archaeology, Iconography, Epigraphy, Ancient Textiles Series 12, 161-188. Oxford.

Soysal, O. 2004 Hattischer Wortschatz in hethitischer Textüberlieferung, Handbuch der Orientalistik I/74. Leiden/ Boston.

Starke, F. 1990 Untersuchungen zur Stammbildung des keilschriftluwischen Nomens, StBoT 31.

Teissier, B. 1994 Sealing and Seals on Texts from Kültepe Kārum Level 2, PIHANS 70.

Ünal, A. 1978, Ein Orakel Text über die Intrigen am hethitischen Hof (KUB XXIII 70 - Bo 2011), Texte der Hethiter 6. Heidelberg.

Veenhof, K. R. 1972 Aspect of old Assyrian Trade and its Terminology, Studia et Documenta ad Iura Orientis Antiqui pertinentia, Volumen X. Leiden.

Veenhof, K. R. 1997 "Modern" Features in Old Assyrian Trade, Journal of the Economic and Social History of the Orient, 40/4, 336-366.

Verderame, L. 2008 Il controllo dei manufatti tessili a Umma. In M. Perna and F. Pomponio (eds), The Management of Agricultural Land and the Production of Textiles in the Mycenaean and Near Eastern Economy, 101-133. Napoli.

Vigo, M. 2010 Linen in Hittite Inventory Texts. In C. Michel and M.-L. Nosch (eds), Textile Terminologies in the Ancient Near East and the Mediterranean Area from the 3rd to the 1st millennium BC, Ancient Textiles Series 8, 288-320. Oxford.

Völling, E. 2008 Textiltechnik im Alten Orient: Rohstoffe und Herstellung. Würzburg. 
Waetzoldt, H. 1972 Untersuchungen zur neosumerischen Textilindustrie, Studi economici e tecnologici 1. Roma. Weeden, M. 2011 Hittite Logograms and Hittite Scholarship, StBot 54.

Wiggermann, F. 2000 Lamaštu, Daughter of Anu, a Profile. In M. Stol (ed.), Birth in Babylonia and the Bible, Its Mediterranean Setting, Cuneiform Monographs 14, 217-252. Groningen.

Winter, I. 1989 The "Hasanlu Gold Bowl": Thirty Years Later. Expedition 31/2-3, 87-106.

Wisti Lassen, A. 2010a The Trade in Wool in Old Assyrian Anatolia. JEOL 42, 159-179.

Wisti Lassen, A. 2010b Tools, Procedures and Professions: A review of the Akkadian textile terminology. In C. Michel and M.-L. Nosch (eds), Textile Terminologies in the Ancient Near East and the Mediterranean Area from the 3rd to the 1st millennium BC, Ancient Textiles Series 8, 270-280. Oxford.

Wisti Lassen, A. 2013 Technology and Palace Economy in Middle Bronze Age Anatolia: the Case of the Crescent Shape Loom Weight. In M.-L. Nosch, H. Koefoed and E. Andersson-Strand (eds), Textile Production and Consumption in the Ancient Near East: Archaeology, Iconography, Epigraphy, Ancient Textiles Series 12, 78-92. Oxford.

Woolley, L. 1955 Alalakh - An Account of the Excavations at Tell Atchana in the Hatay, 1937-1949, Reports of the Research Committee of the Society of Antiquaries of London 18. Oxford.

Yakar, J. and Taffet, A. 2007 The Spiritual Connotations of the Spindle and Spinning: Selected Cases from Ancient Anatolia and Neighbouring Lands. In M. Alparslan, M. Doğan-Alparslan and H. Peker (eds), Belkıs Dinçol ve Ali Dinçol'a Armağan. VITA. Festschrift in Honor of Belkıs Dinçol and Ali Dinçol, 781-788. Istanbul.

Yıldırım, T. 2009 Hüseyindede: a Settlement in Northern Central Anatolia - Contributions to Old Hittite Art. In F. Pecchioli Daddi, G. Torri and C. Corti (eds), Central-North Anatolia in the Hittite Period. New Perspectives in Light of Recent Research. Acts of the International Conference Held at the University of Florence (7-9 February 2007), Studia Asiana 5, 235-246. Roma.

Yon, M., Caubet, A., Mallet, J., Lombard, P., Doumet, C. and Desfarges, P. 1983 Ras Shamra-Ougarit 1981-1983 (41e, 42e et 43e campagnes). Syria 60, 201-224.

Yon, M., Lombard P. and Renisio, M. 1987 L'organisation de l'habitat. Les maisons A, B et E. In M. Yon (ed.) Ras Shamra-Ougarit 3. Le Centre de la Ville, 38e-44e campagnes (1978-1984), 11-128. Paris.

Zawadski, S. 2006 Garments of the Gods. Studies on the Textile Industry and the Pantheon of Sippar according to the Texts from the Ebabbar Archive, Orbis Biblicus et Orientalis 218. Freibourg/Göttingen.

Ziffer, I. 2002 Four New Belts from the Land of Ararat and the Feast of the Women in Esther 1:9. In S. Parpola and R. M. Whiting (eds), Sex and Gender in the Ancient Near East. Proceedings of the 47th Rencontre Assyriologique Internationale, Helsinki, July 2-6, 2001, 645-657. Helsinki. 